\title{
Application of Nano Bio-clay Composite in a Scaling-up Study for Wastewater Treatment
}

\author{
Ahmed Hamd ${ }^{1,2}$, Doaa Rady ${ }^{3}$, Mohamed Shaban ${ }^{2,4}$, Khaled N. M. Elsayed ${ }^{5}$, Hamad Al Mohamadi ${ }^{6}$, Ali \\ M. Elzanaty ${ }^{3}$, Sayed A. Ahmed ${ }^{7}$, Refat El-Sayed ${ }^{8,9}$, Nofal Khamis Soliman ${ }^{1, * \text { (D }}$ \\ Basic Science Department, Nahda University Beni-Suef (NUB), Beni Suef, Egypt \\ 2 Nanophotonics and Applications Lab, Physics Department, Faculty of Science, Beni-Suef University, Beni Suef 62514, \\ Egypt \\ 3 Department of Chemistry, Faculty of Science, Beni-Suef University, Beni Suef 62511, Egypt \\ 4 Department of Physics, Faculty of Science, Islamic University in Almadinah Almonawara, Almadinah Almonawara, \\ 42351, Saudi Arabia \\ 5 Department of Botany, Faculty of Science, Beni-Suef University, Beni-Suef 62511, Egypt \\ 6 Department of Chemical Engineering, Faculty of Engineering, Islamic University of Madinah, Madinah, Saudi Arabia \\ 7 Research Institute of Medicinal and Aromatic Plants (RIMAP), Beni-Suef University, Beni Suef, Egypt \\ 8 Chemistry Department, Faculty of Applied Sciences, Umm Al-Qura University, Mecca, Saudi Arabia \\ 9 Chemistry Department, Faculty of Science, Benha University, Benha, Egypt \\ * Correspondence: nofal.khamis@nub.edu.eg (N.K.S.);
}

Received: 14.08.2021; Revised: 15.10.2021; Accepted: 19.10.2021; Published: 18.11.2021

\begin{abstract}
A scaling-up study integrating experimental and field experiments was managed to explore the most appropriate catalysis method to assist industries in getting rid of the Congo Red (CR) dye from industrial wastewater. The adsorption potential of kaolinite (K) modified by Ulva Lactuca (UL) was evaluated to eliminate CR dye from aqueous solutions. The novel kaolinite/alga nanocomposite (KUL) was synthesized following steps of the wet impregnation method and then subjected to characterization using different techniques. The newly reported KUL nanocomposite shows a significant increase in adsorption ability higher than that of K and UL. To research different experimental factors' effects, batch experiments were evaluated, and each of the kinetics/isotherms of CR adsorption were explored either. The CR removal\% is clearly affected by catalyst dose, working temperature, and $\mathrm{pH}$ value with high percentage. The best temperature for $\mathrm{CR}$ adsorption onto KUL is $400 \mathrm{C}$ at $\mathrm{pH}>7$. CR adsorption on KUL following the first-order diffusion model, while K and UL appeared to follow two different kinetic adsorption models depending on the CR concentration. Moreover, the field tests (scaling-up experiments) revealed optimistic results with $91 \%$ efficiency for KUL nano-adsorbents in eliminating mixed dyes from industrial wastewater, which means the foundation of novel environmentally benign nano-adsorbents to help in industrial wastewater recycling.
\end{abstract}

Keywords: kaolinite (K); Ulva Lactuca (UL) alga; nanocomposite; industrial wastewater; adsorption; dyes removal.

(C) 2021 by the authors. This article is an open-access article distributed under the terms and conditions of the Creative Commons Attribution (CC BY) license (https://creativecommons.org/licenses/by/4.0/).

\section{Introduction}

Nobody can deny the importance of water as an essential source for the subsistence of life on the earth. While industrialization and invention improved humanity's lifestyle, they were also the main reason for the pollution of clean water supplies [1-3]. Not only are heavy metal ions, dye molecules, pharmaceutical molecules, surfactant molecules, pesticides, personal hygiene products, and some other substances considered everyday sources of pollution of pure 
and minimal water supplies, but they also harm all living species [4-8]. Synthetic dyes developed by various industrial sectors such as paper, rubber, textiles, pigments, cosmetics, plastics, and printing leave many water contaminants $[7,9,10]$.

Dyes are used in a wide range of industries to color products and enhance the status of the products [11-14]. This great expansion of using dyes leads to Water Pollution in the environment $[15,16]$. These dyes are known for their toxicity, stability, and nonbiodegradability to a large degree [17-19], and it causes genetic mutations, cancers, fractures in different chromosomes, and toxicity in the respiratory system [20, 21]. For example, when exposed to CR dye, he will sever from serious eye and skin irritation in a few minutes. In addition to the ingestion of Congo red can result in stomach irritation, nausea, vomiting, and diarrhea [22]. Removing dyes from solutions using either physical, chemical, or biological techniques is all reported. Filtration, reverse osmosis, flotation, electrochemical, dilution, coagulation, membrane separation process, reverse osmosis, and softening technologies have been used for this proposal [23-27].

Compared to the above techniques, adsorption is the most convenient because it is inexpensive, quick, less maintenance, easy to manage, and sediment levels are smaller than the other methods [26, 28-33].In the last decades, dye elimination from wastewaters using cheap and efficient adsorbents such as biomass wastes, fly ashes, algae, mineral clays, and agricultural wastes was studied [5, 34-37]. This is ascribed to the presence of active functional groups that inspire contaminants attached to the wall of the biomaterial; these functional groups may be carboxylic, hydroxyl, amino, carbonyl, phosphate, or sulfonic [38, 39]. The importance of kaolinite as a clay mineral used in many industrial products has been reported, including its uses in eco-friendly treatments, constructions, papers, paints, refractories, ceramics, and plastics [40, 41]. This is due to its strong adsorption properties [42]. Kaolinite, with the chemical formula $\left[\mathrm{Al}_{2} \mathrm{Si}_{2} \mathrm{O}_{5}(\mathrm{OH})_{4}\right]$ and layer structure stacked in the order $(1: 1)$ where each separate layer reveals a sheet from $\mathrm{Si}_{2} \mathrm{O}_{5}{ }^{2-}$ tetrahedrons in addition to the alumina $\left[\mathrm{Al}_{2}(\mathrm{OH})_{4}\right]^{2+}$ octahedrons, these sheets bind together through mutual oxygen atoms keeping their lamellar structures through the hydrogen bonds [43-45]. The location of hydroxyl groups $(\mathrm{OH})$ in kaolinite structure is considered the most important feature as they are involved in various chemical reactions $[46,47]$.

In our work, a scaling-up study including laboratory and semi-pilot scale experiments was conducted to find the most appropriate catalysis system that effectively removes waste dyes, especially Congo Red dye, from industrial wastewater. The adsorption performance of K, UL, and KUL nanocomposite was studied for Congo red dye removal from wastewater under different experimental conditions to investigate the effects of UL on K's adsorption capability. UL and K were chosen for several factors, including their natural abundance, lowcost processing, cheap reusability, and recyclability. These factors play a major economic character in applying and generalizing this low-cost technique. Batch experiments were performed, including studying the effect of starting CR concentrations, reaction times, nano adsorbent doses, reaction temperatures, and $\mathrm{pH}$ values on $\mathrm{CR}$ dye removal\%. Adsorption isotherms and kinetics are also studied. 


\section{Materials and Methods}

\subsection{Raw materials, dyes, and reagents.}

Kaolinite ore was supplied from El-Nassr company for mining and used as it without any further modification. UL macroalga was collected from the inter-tidal area of Egyptian Red Sea shores at a distance between Quoseir and Marsa-Alam cities. Congo Red dye was purchased from Sigma Aldritch and subjected to dissolving in distilled water. Granules of sodium hydroxide with purity $99.99 \%$ and $36 \%$ hydrochloric acid were supported by Sigma Aldrich and used for $\mathrm{pH}$ adjustment.

\subsection{Preparation of kaolinitelalga (KUL) nanocomposite.}

The kaolinite/alganano-composite (KUL) was synthesized through a wet impregnation technique [48, 49]. Kaolinite/algae nanocomposite was prepared by the following steps; in the first step, $1 \mathrm{gm}$ of kaolinite $+1 \mathrm{gm}$ of algae were mixed with $20 \mathrm{ml}$ of deionized(DI) water then magnetically stirred at $500 \mathrm{rpm}$ for $60 \mathrm{~min}$ then in ultrasonic for $60 \mathrm{~min}$ and repeated for 3 times after that, it the resultant kaolinite/algae nanocomposite was subjected to filtration, wash using DI water for many periods, and finally dried using a vacuum oven at $60{ }^{\circ} \mathrm{C}$ during $24 \mathrm{~h}$. The K, UL, and KULnano-composites were subjected to crystallographic characterization using X-ray diffractometer (XRD), surface characterization using Scanning electronic microscope (SEM), and finally active function groups using Fourier transformer- infrared (FTIR) spectrometer, and optical spectroscopy.

\subsection{Preparation of adsorbate.}

The regular and well-known anionic dye, Congo red (CR), was chosen as the adsorbate in this study.CR dye is a sodium-based salt of 3,30-([1,10-biphenyl]-4,40-diyl) bis (4-amino naphthalene-1-sulfonic acid) with a molecular formula: $\mathrm{C}_{32} \mathrm{H}_{22} \mathrm{~N}_{6} \mathrm{Na}_{2} \mathrm{O}_{6} \mathrm{~S}_{2}$. Figure $\mathrm{S} 1$ (Supplementary data) illustrates the structure of the CR dye. A $1000 \mathrm{mg} / \mathrm{l}$ solution in stock was prepared by dissolving an adequate amount (1000mg) of CR in $1000 \mathrm{ml}$ of DI water. Then, the stock was diluted by DI water to obtain the required concentrations of the working solutions. The $\mathrm{pH}$ of all prepared solutions was adjusted to 3, 5, 7, and 10 using either $0.1 \mathrm{M}$ solution of $\mathrm{HCl}$ or $\mathrm{NaOH}$.

\subsection{Samples characterizations.}

The XRD characterization was carried out by PANalytical diffractometer (Empyrean) using CuK $\alpha$ of wavelength $\lambda \alpha=0.154045 \mathrm{~nm}$ and operating at $40 \mathrm{kV}, 35 \mathrm{~mA}$ with scan step of $0.02^{\circ}$ within the range $20-70^{\circ}$. The average crystallite size, $D_{s}$, of the prepared nanoparticles was obtained by Scherer formula, $D_{\mathrm{s}}=0.94 \lambda \alpha / \beta_{\mathrm{w}} \cos \phi$; where $\beta_{\mathrm{w}}$ and $\phi$ are the corrected full width at half maximum and the diffraction angle [50]. SEM micrographs were measured using Quanta FEG 250 microscope (Switzerland). FT-IR spectra were measured using a Bruker VERTEX 70 FT-IR spectrophotometer using the dry KBr pellet technique.

\subsection{Adsorption studies.}

Batch mode scale was selected for all CR adsorption experiments in various conditions, including initial CR concentrations (5 - 25 mg / ), contact time (up to $480 \mathrm{~min}$ ), adsorbent 
dosage $(10-50 \mathrm{mg}), \mathrm{pH}(3-10)$, and temperature $\left(25-90^{\circ} \mathrm{C}\right)$ with shaking during the time. A series of four adsorption experiments were implemented on K, UL, and KUL adsorbents at diverse adsorption circumstances; these experiments included initial dye concentration, the temperature of adsorption, adsorbents dose, and initial $\mathrm{pH}$ of the solution as displayed in Table S1 (Supplementary data). The experiment time was set at 480 minutes with $25 \mathrm{ml}$ solution volumes in all experiments. The variation in the CR concentration was elucidated from the absorption peak measured by UV/Vis spectrophotometer.

The reusability tests of both K, UL, and KUL adsorbents were examined 5 times using $0.02 \mathrm{~g}$ of all adsorbents, $25 \mathrm{ml}$ of $10 \mathrm{mg} / \mathrm{L}$ initial concentration of CR for 480minutes contact time at $25^{\circ} \mathrm{C}$ and $\mathrm{pH} 7 . \mathrm{K}$, UL, and KUL adsorbents were collected from the solution after each run, then cleaned from dye residues by distilled water and set for the next run.

The quantity of CR uptake by the synthesized nanocomposite at equilibrium $\left(\mathrm{q}_{\mathrm{e}}(\mathrm{mg} / \mathrm{g})\right.$ and time $\mathrm{t}\left(\mathrm{q}_{\mathrm{t}}\right)$ and $\mathrm{CR}$ dye removal\% have been obtained utilizing equations 1 and 2 , respectively $[7,51]$ :

$$
\begin{gathered}
\mathrm{q}_{\mathrm{i}}=\left(C_{o}-C_{i}\right) \frac{V}{m} ; \mathrm{i}=\mathrm{e}, \mathrm{t} \\
\text { CR dye removal } \%=\frac{\left(C_{o}-C_{t}\right)}{C_{o}} \times 100
\end{gathered}
$$

$\mathrm{C}_{\mathrm{o}}, \mathrm{C}_{\mathrm{t}}$, and $\mathrm{C}_{\mathrm{e}}$ are the concentrations of $\mathrm{CR}$ in $\mathrm{mg} / \mathrm{l}$ at the start, after time $\mathrm{t}$, and at equilibrium e, respectively. $\mathrm{V}$ is the $\mathrm{CR}$ volume in $\mathrm{mL}$, and $\mathrm{m}$ is the $\mathrm{K}$, $\mathrm{UL}$, and KUL mass in mg.

\subsection{Adsorption isotherms, kinetics, and mechanisms.}

Langmuir, Freundlich, and Tempkin isotherms have been applied to explain the reaction isotherm of the fabricated K, UL, and KUL nanocomposites for the tested CR [52-55].

The degree of favorability of the Langmuir isotherm for the equilibrium data could be predicted from the value of the dimensionless separation factor $\left(\mathrm{R}_{\mathrm{L}}\right)$ based on equation 3 [56].

$$
R_{L}=\frac{1}{\left(1+K_{L} C_{\max }\right)}
$$

Where $\mathrm{C}_{\max }$ represents the maximum initial CR concentration.

Different adsorption mechanisms and kinetics models such as intra-particle diffusion, pseudo-first-order,pseudo-second-order, and simple Elovich kinetic model are used for identifying the adsorption mechanisms and kinetics models that best match with the adsorption of CR onto K, UL, and KUL adsorbents [4-6, 57-60]. All linear isotherms and kinetics equations and their parameters are explained in supplementary data.

\subsection{Statistical analyses.}

All adsorption results were measured in triplicates, and the average values were presented. The values of regression coefficients $\left(\mathrm{R}^{2}\right)$ for the different kinetic and isotherm models were obtained using the statistical functions of OriginPro 2016.

\subsection{Field experiments.}

The newly synthesized catalysis system was tested as an effective eco-friendly catalyst that could be applied on a large scale to remove industrial waste dye from industrial wastewater. For this purpose, wastewater containing waste dye was supported by clothes dying plants in 
Beni-Suef city. The wastewater containing waste dye was used as it is without any further treatment or dilution. The appropriate catalysis system was selected depending on our adjusted computational and experimental results.

\section{Results and Discussion}

\subsection{Adsorbent characterizations.}

\subsubsection{SEM characterization.}

Figure 1 illustrated SEM images of K, UL, and KUL adsorbents. Figure 1A shows agglomerated rounded regular shape particles, rough surfaces, different particle sizes, and porous cavities on the surface for kaolinite. The SEM image of UL, Figure 1B, shows that UL exhibits a less porous surface, consequently affecting the surface area for UL, which affects its adsorption capacity. When kaolinite is treated with algae UL, the SEM image of the nanocomposite, Figure 1C, shows that the pores in the kaolinite surface are covered with the UL particles and converted into agglomerated particles. The formation of the KUL nanocomposite could be established from the noted changes in the morphology of the nanocomposite relative to that observed for K and UL.
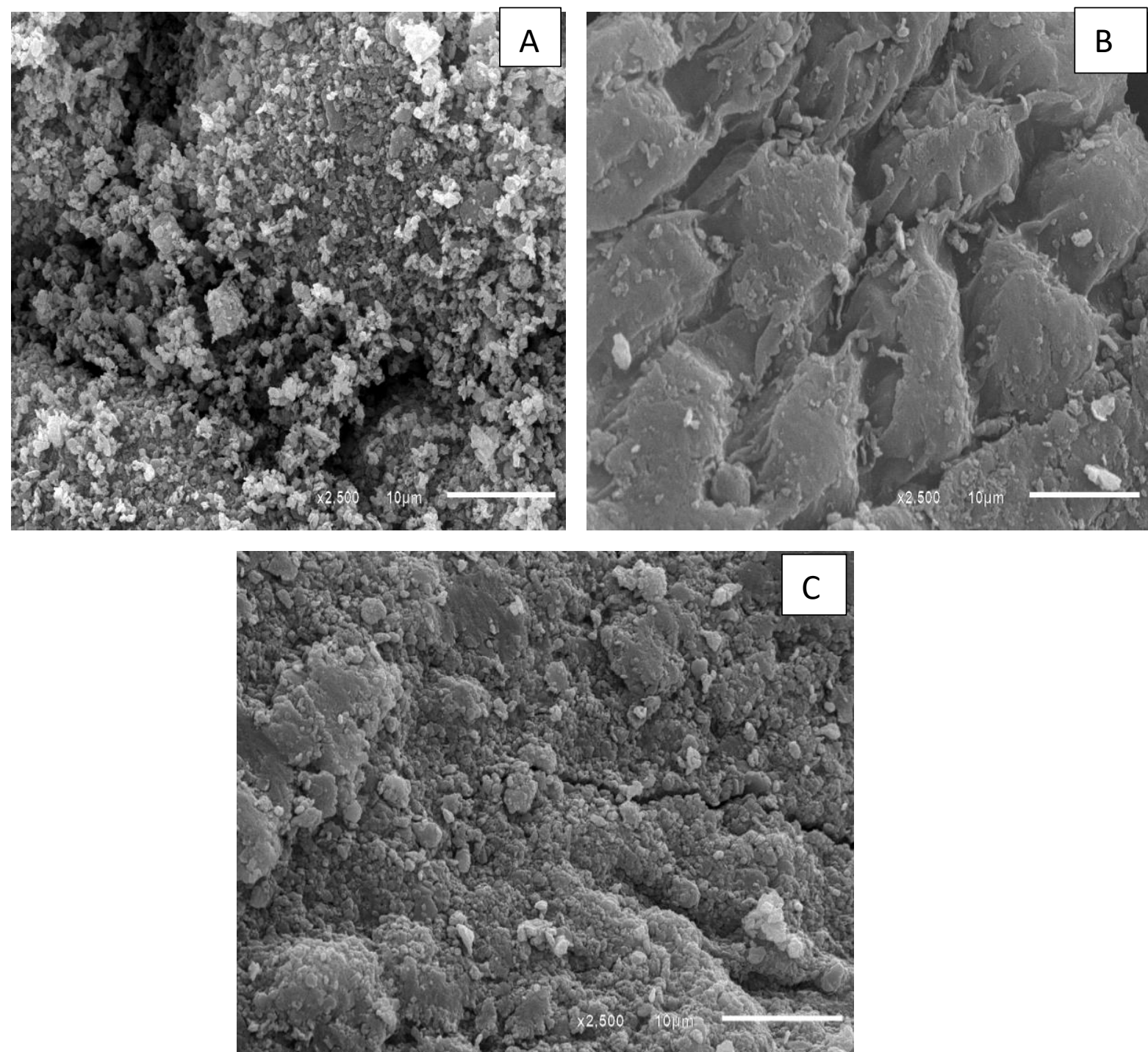

Figure 1. SEM micrographs of (A) K, (B) UL, and (C) KUL adsorbent. 


\subsubsection{FT-IR analyses.}

The FT-IR charts of K, UL, and KUL adsorbent are displayed in Figure 2A. The FT-IR spectrum of K, Figure 2A(red color) illustrated a wide mode of $\mathrm{OH}$ groups. The modes at 3691 and $3621 \mathrm{~cm}^{-1}$ refer to the inner $\mathrm{OH}$ stretching [61-63]. The peaks at 1109 and $1023 \mathrm{~cm}^{-1}$ are related to Si-O vibration modes [64]. The peaks at 469, 543, and $919 \mathrm{~cm}^{-1}$ are related to the Si-O-Si bending, Si-O-Al, and octahedral aluminum (Al-OH) [65]. The peaks that appeared in the region from 400 to $800 \mathrm{~cm}^{-1}$ are related to the metal oxides [66].

From the FT-IR chart of UL algae, Figure 2A (blue color), the band at $3777 \mathrm{~cm}^{-1}$ characterizes an amine group (-NH) stretching, and the band at $3424 \mathrm{~cm}^{-1}$ characterizesof the hydroxyl function $(-\mathrm{OH})$ of phenolic groups. The peak at $2928 \mathrm{~cm}^{-1}$ was allocated to the stretching mode of alkyl groups $-\mathrm{CH}$, whereas the mode at $1618 \mathrm{~cm}^{-1}$ corresponded to $-\mathrm{C}=\mathrm{O}$. The band at $1429 \mathrm{~cm}^{-1}$ was attributed to the $\mathrm{C}-\mathrm{H}$ vibration $[35,67]$. The bands located around 1110,1120 , and $1140 \mathrm{~cm}^{-1}$ are attributed to the $\mathrm{C}-\mathrm{O}$ bond or refer to the sulfate group [68]. The bands at $3300-3500 \mathrm{~cm}^{-1}$ and $2500-3000 \mathrm{~cm}^{-1}$ are referred to as amine $\mathrm{N}-\mathrm{H}$ stretching and carboxylic acid $\mathrm{O}-\mathrm{H}$ stretching, respectively [69].
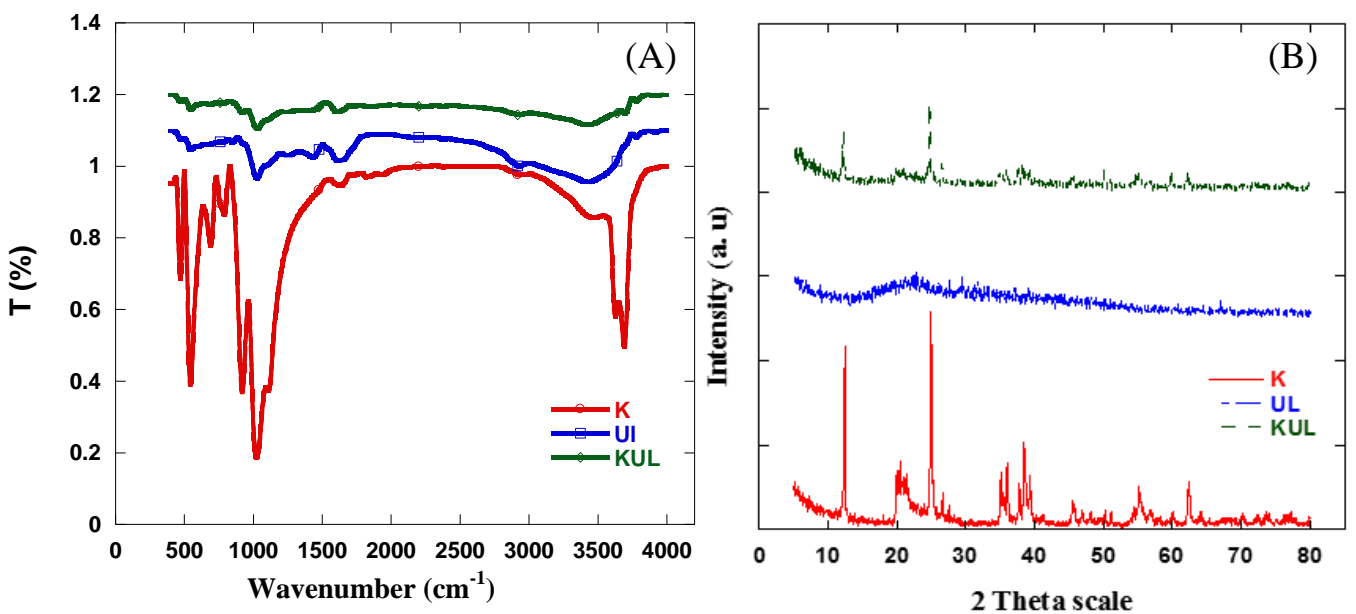

Figure 2. (A) FTIR and (B) XRD charts of K, UL, and KUL adsorbents.

Finally, FT-IR peaks of the newly synthesized catalyst KUL are shown in Figure 2A (green color). The characteristic peaks representing the two phases (kaolin and algae) confirm the presence of a new compound. Some peaks disappeared, especially those representing the amino group in the algae, which confirms the interlocking between algae and kaolin's pores and surface molecules. Peak disappearance was noticed, and the peak shift happened for characteristic peaks for both kaolin and algae. Both the peak shift and peak disappearance come in line with data obtained from other characterization techniques, which confirms the formation of a new compound. Table S2, supplementary data, lists the positions of the characteristic FTIR bands for K, UL, and KUL adsorbents.

\subsubsection{XRD characterization.}

The XRD charts of K, UL, and KUL are presented in Figure 2B. The main XRD peaks of kaolinite minerals were observed at 2theta of about $12.44^{\circ}$ and $24.9^{\circ}$ due to the crystallographic growth alongside the (001)and (002) planes [70, 71]. Additional kaolinite peaks are observed at about $19.91^{\circ}, 35.06^{\circ}, 36.05^{\circ}, 38.50^{\circ}, 39.30^{\circ}$, and $62.48^{\circ}$. The obtained d-spacing of the main kaolinite peak at $12.44^{\circ}$ is $7.11824 \AA$. The XRD chart of UL shows sharp peaks at $12.51^{\circ}$, 
$22.94^{\circ}, 23.66^{\circ}, 25.00^{\circ}$, and $29.3^{\circ}[67,72]$. The XRD chart of KUL displays a small shift in the position of the main XRD peaks of kaolinite to shift to $12.28^{\circ}$ and $24.71^{\circ}$. In addition to the appearance of another peak at $38.30^{\circ}$. The average calculated crystallite size using the Scherer equation was $40.3 \mathrm{~nm}$, which confirms the nanoscale nature of the newly synthesized composite.

\subsection{Factors influencing the adsorption process.}

\subsubsection{Influence of initial CR concentration.}

The variations in the removal\% and the amount of CR adsorbed with time using K, UL, and KUL nano adsorbents at different initial CR concentrations are shown in Figures 3 (A-C) and 3(D-F), respectively. It can be observed from these Figures that; the dye removal \% and the adsorption capacity were very high throughout the primary stage of the entire adsorption process, and after that, their increasing rates are reduced to reach the equilibrium state at the end. It was also observed that; contact time has no marked effect on the adsorption process using new sorbents after reaching the equilibrium. The prompt removal rates at the early stage of the reaction are allocated to the existence of a huge surface density of uncovered active spots on the nano adsorbent's surfaces by increasing the contact period between adsorbent and adsorbate, and the hot spots are converted to fully occupied sites byCR molecules. As a result, repulsion forces are established between the adsorbed CR molecules on the surface of adsorbents and CR molecules in the bulk liquid phase [7].

The KUL nanocomposite revealed higher efficiency for Congo red adsorption at lower concentrations compared with K and UL. At 5 and $10 \mathrm{ppm}$ initial dye concentration, the CR removal\% was $99 \%$ and $92 \%$ for KUL, $81 \%$ and $73 \%$ for UL; and $37.7 \%$ and $28.7 \%$ for K, respectively. This trend is inlined with previously reported composites with lower performance than the present $[41,73-75]$. With increasing concentration to $15 \mathrm{ppm}$, the dye removal $\%$ reaches $70 \%$ for both KUL and UL, and $23.3 \%$ for $\mathrm{K}$ adsorbent. At relatively high concentrations, 20 and $25 \mathrm{ppm}$, the dye removal \% was in the order UL >KUL >K.

The quantities of adsorbed CR are increased by raising the starting CR concentration, as shown in Figure 3(D-F). This could be attributed to the increase in the concentration gradient as the initial CR concentration increases. Therefore, an appropriate increase in the draft forces occurs to overawed the mass transfer resistance between CR adsorbates and K, UL, and KUL nano adsorbents [76]. 1.88, 2.8, 3.5, 4.4, and $5.0(\mathrm{mg} / \mathrm{g})$ were found to be the K's maximum adsorption capacities, while $4.5,7.3,10.5,13.18$, and $15.5(\mathrm{mg} / \mathrm{g})$ were found to be the adsorption capacities of UL for CR dye with initial concentrations of 5, 10, 15, 20 and $25 \mathrm{mg} / \mathrm{l}$, respectively, at $\mathrm{pH} 7$ and $25^{\circ} \mathrm{C}$. Whereas, the KUL maximum adsorption capacities were found to be $4.9,9.2,10.5,10.58$, and $8.4(\mathrm{mg} / \mathrm{g})$ at these starting concentrations. The results showed that the modification of $\mathrm{K}$ with $\mathrm{UL}$ is a feasible approach to enhance the $\mathrm{CR}$ removal performance by $\mathrm{K}$ at lower concentrations.

\subsubsection{Influence of nanoadsorbent dosage.}

To determine the adsorption cost, the influence of the nano adsorbent dose on the CR removal\% was assessed for determining the optimized nano adsorbent dosage that offers the maximum performance. This is graphically depicted in Figure 4a. The adsorbent doses were varied from 0.01 to $0.05 \mathrm{~g}$. It was found that $0.02 \mathrm{~g}$ nano adsorbent per $20 \mathrm{ml} \mathrm{CR}$ solution of 10 
$\mathrm{mg} / \mathrm{l}$ starting concentration was the best nano adsorbent dosage. From Figure 4a, The CR removal $\%$ for all adsorbents rises as the nano adsorbent dosage increases from 0.01 to $0.02 \mathrm{~g}$. The removal\% increases from $26 \%$ to $28.7 \%$ in the case of $\mathrm{K}$ adsorbent, while it increases from $55 \%$ to $73 \%$ in the case of UL adsorbent and increases from $80 \%$ to $92 \%$ in the case of KUL adsorbent.
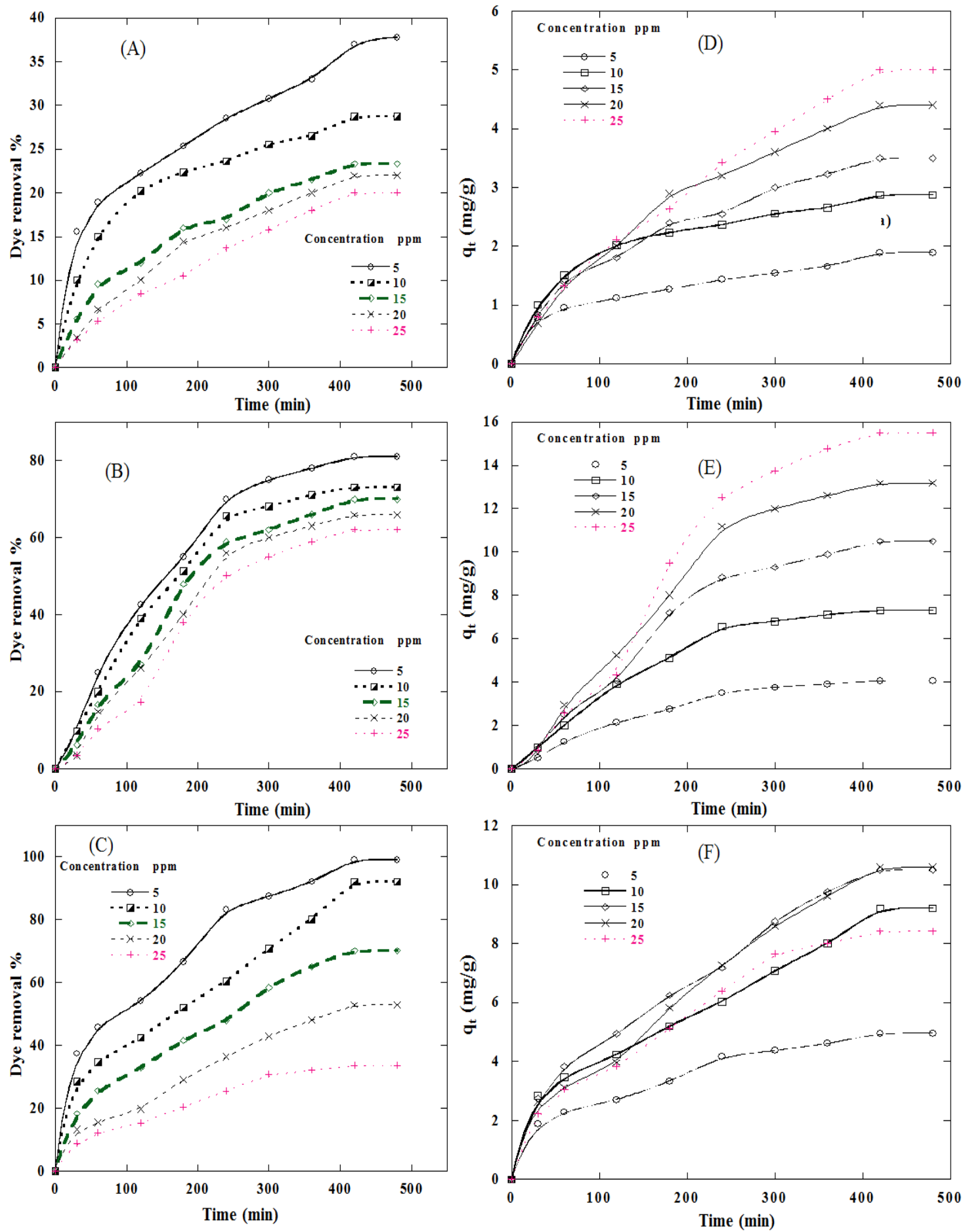

Figure 3. Effect of $\mathrm{CR}$ dye concentration and contact time on the removal\% and the amount of $\mathrm{CR}$ dye adsorbed at $25^{\circ} \mathrm{C}$ and $\mathrm{pH} 7$ by $20 \mathrm{mg}$ of (A, D) K, (B, E) UL, and (C, F) KUL.

This observation refers to increasing the number of active dots with increasing the nano adsorbent dosage [7]. For nano adsorbent dosage over $0.02 \mathrm{~g}$, the removal\% decreases again. For $\mathrm{K}$ adsorbent, the $\mathrm{CR}$ removal\% decreases to $\sim 25 \%, 22 \%$, and $15 \%$, increasing the adsorbent dose to $0.03,0.04$, and $0.05 \mathrm{~g}$, respectively. For UL adsorbent, the CR removal\% 
decreases to 68,54 , and $46 \%$, increasing the adsorbent dose to $0.03,0.04$, and $0.05 \mathrm{~g}$, respectively. Also, the CR removal\% decreases to 25,22 , and $15 \%$, in the case of KUL adsorbent, by increasing the adsorbent dose to $0.03,0.04$, and $0.05 \mathrm{~g}$, respectively. This finding may be ascribed to the screening effect that occurs at elevated nano adsorbent dosage due to the accumulation of the nano adsorbent particles and decreasing the distance between the nano adsorbent particles. The condensed layer at the surface of the adsorbent hid the binding sites from CR molecules. Also, K, UL, and KUL overlapping resulted in a competition between CR molecules for limited numbers of available binding sites. Aggregation or agglomeration at greater K, UL, and KUL doses also increase the CR diffusion path length, causing a decrease in adsorption \% [5, 77-79].
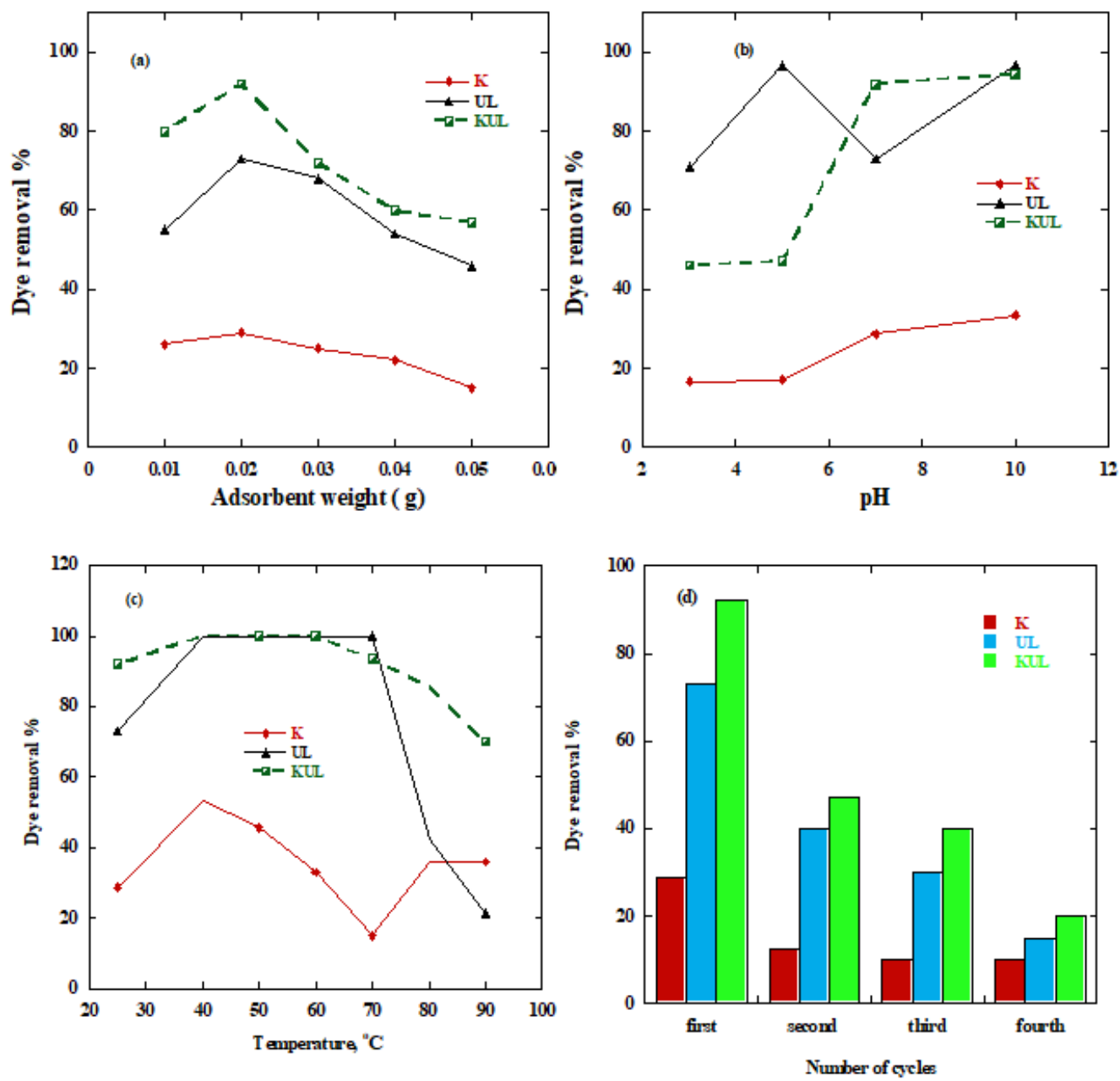

Figure 4. Effect of (a) adsorbent weight, (b) Initial pH of the solution, (c) adsorption temperature, and (d) reusability test on the removal\% of $20 \mathrm{ml} \mathrm{CR}$ solution of $10 \mathrm{mg} / \mathrm{l}$ by $\mathrm{K}$, UL, and KUL.

\subsubsection{Influence of $\mathrm{pH}$.}

Due to its influence on the dissociation/ionization of the K, UL, and KUL nano adsorbents and their impact on the absorbent surfaces, the starting $\mathrm{pH}$ value of the CR solution can be a crucial player in controlling the nano adsorbent performance [69]. So, the electrostatic charges on the K, UL, and KUL sorbents and the CR sorbate are greatly affected by the $\mathrm{pH}$ of the solution. The effect of $\mathrm{pH}$ on the CR removal efficiency of the adsorbent was studied between $\mathrm{pH} 3$ and $\mathrm{pH} 10$ as shown in Figure $4 \mathrm{~b}$ at $10 \mathrm{mg} / \mathrm{l}$ of CR dye initial concentration and $0.02 \mathrm{~g}$ of adsorbent dosage. The $\mathrm{K}$ adsorbent shows removal percentages of $16.6 \%, 17.0 \%$, $28.7 \%$, and $33 \%$ for CR solutions of $\mathrm{pH} 2,5,7$, and 10, in that order. The UL adsorbent shows 
removal percentages of $71.0 \%, 96.6 \%, 73.0 \%$, and 96.0\%, while KUL adsorbent shows removal $\%$ of $46.0 \%, 47.0 \%, 92.0 \%$, and $94.5 \%$ at $\mathrm{pH} 2,5,7$, and 10 , respectively, at the same formerly mentioned conditions.

The CR dye removal\% generally increases with increasing the $\mathrm{pH}$ of CR solution from $\mathrm{pH} 2$ to $\mathrm{pH} 10$. The lower removal\% was obtained at $\mathrm{pH} 2$, which may attribute to the high mobility of $\mathrm{H}^{+}$ions and the nano adsorbent surface protonation. Thus, the $\mathrm{CR}$ removal\% decreases due to the competition between $\mathrm{H}^{+}$ions and $\mathrm{CR}$ molecules during the adsorption process [80]. But at a higher $\mathrm{pH}$ value, the observed elevation in the $\mathrm{CR}$ removal\% by all adsorbents is ascribed to the decrease of $\mathrm{H}^{+}$ions concentration [81]. For UL adsorbent, the high elimination $\%$ of $\mathrm{CR}$ at $\mathrm{pH} 5$ may attribute to the creation of accumulated +ve charges on the UL surfaces due to the protonation of the polar functional groups presented on the surface of the adsorbent in acid medium. The positively charged adsorbent surface strongly attracts the CR anions [82].

\subsubsection{Influence of temperature.}

The effect of temperature on the CR dye uptake\% onto K, UL, and KUL was followed up at various adsorption temperatures. The adsorption tests were done at 25, 40, 50, 60, 70, 80, and $90^{\circ} \mathrm{C}$. The data are presented in Figure $4 \mathrm{c}$. For both UL and KUL adsorbents, the CR removal\% is increased from $73 \%$ to $100 \%$ and from $92 \%$ to $100 \%$, respectively, with rising temperatures from $25^{\circ} \mathrm{C}$ to $40^{\circ} \mathrm{C}$. This performance could be owed to the growth of the $\mathrm{CR}$ diffusion rates with rising temperature due to the decrease in viscosity of the solution [83]. With more temperature rise, the $\mathrm{CR}$ removal\% remains constant at $100 \%$ till $70^{\circ} \mathrm{C}$ for UL adsorbent and till $60^{\circ} \mathrm{C}$ for KUL adsorbent. This could be attributed to the fact that the maximum limit of $\mathrm{CR}$ adsorption is reached by the nano adsorbent. With more and more increases in temperature, the dye removal\% drops down again, and this is owed to the collapse of adsorption force responsible for CR dye molecule adsorption on the UL and KUL surfaces [84]. This may ascribe to active site damage and adsorptive force reduction between nano adsorbents active site and CR molecule [19, 85, 86]. So, the optimum temperature for adsorption of CR is from 40 to $70^{\circ} \mathrm{C}$ for UL and from 40 to $60^{\circ} \mathrm{C}$ for $\mathrm{KUL}$ adsorbent.

For $\mathrm{K}$ adsorbent, $\mathrm{CR}$ elimination\% increased with the elevation of the adsorption temperature, where it increased from 28.7 to $53.3 \%$ with changing temperature from 25 to $40^{\circ} \mathrm{C}$. With further increase in temperature, from 40 to $70^{\circ} \mathrm{C}$, the $\mathrm{CR}$ elimination $\%$ reduced from 53.8 to $15.0 \%$. By increasing the temperatures from $25^{\circ} \mathrm{C}$ to $40^{\circ} \mathrm{C}$, the $\mathrm{CR}$ removal\% increases due to the increase in the $\mathrm{CR}$ diffusion rate. The decrease in the $\mathrm{CR}$ elimination\% at elevated temperatures could be attributed to the desorption of CR molecules caused by the destruction of the adsorptive forces responsible for $\mathrm{CR}$ dye adsorption on the $\mathrm{K}$ nano adsorbent surfaces[84]. With a further increase in temperature from 70 to $90^{\circ} \mathrm{C}$, the removal $\%$ increased from 15 to $36 \%$. The best temperature for CR adsorption onto $\mathrm{K}$ is $40^{\circ} \mathrm{C}$.

\subsubsection{Reusability of adsorbents.}

The K, UL, and KUL reusability for eliminating CR was performed four 4 times with the same adsorbent and the same adsorbent dosage, Figure 4d. The results revealed that; the removal strength of K, UL, and KUL adsorbents significantly changed throughout the four adsorption cycles. For $\mathrm{K}$ adsorbent, the recorded dye removal\% was $28.7 \%$ @ $1^{\text {st }}$ cycle, $12.5 \% @ 2^{\text {nd }}$ cycle, 10\%@ $3^{\text {rd }}$ cycle, and $\sim 10 \% @ 4^{\text {th }}$ cycle. For UL adsorbent, the dye removal\% 
was decreased from 73\%@ $1^{\text {st }}$ cycle to $15 \% @ 4^{\text {th }}$ cycle. For KUL adsorbent, a decrease in the calculated CR removal\% occurs where it changes from 92\%@ $1^{\text {st }}$ cycle to $20 \% @ 4^{\text {th }}$ cycle. The drop in the CR removal\% could be attributed to the agglomeration of the CR dye molecules onto the K, UL, and KUL adsorbents surface. Which consequently hind adsorbent surface and pores from the dissolved CR dye molecules, and so, a drop in adsorption capacity of K, UL, and KUL adsorbents take place [87].

Table 1. Isotherm parameters for CR adsorption on K, UL, and KUL.

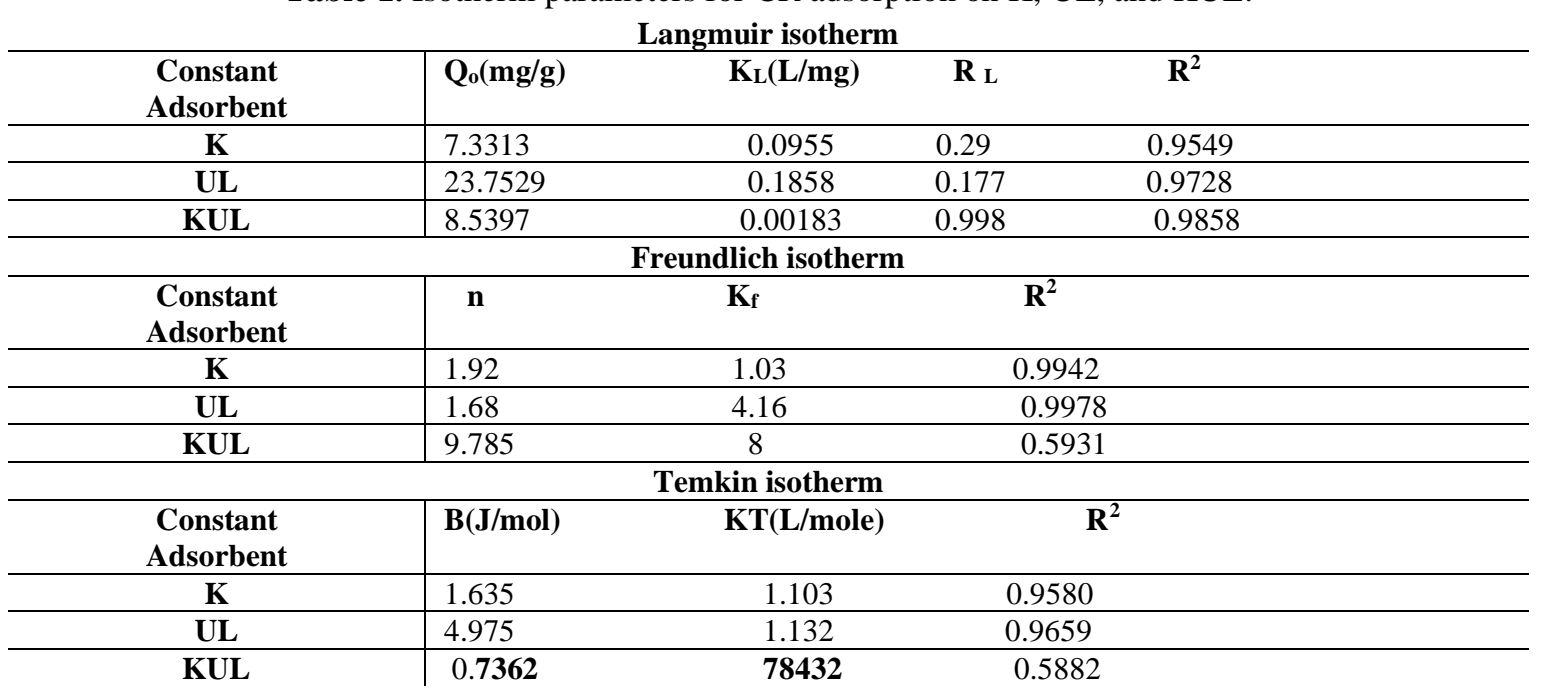

\subsection{Adsorption isotherm.}

The statistical importance of the correlation coefficient $\left(R^{2}\right)$ for the linear fitting of $\mathrm{q}_{\mathrm{e}}$ versus $\operatorname{Ln}\left(\mathrm{C}_{\mathrm{e}}\right), \log \left(\mathrm{q}_{\mathrm{e}}\right)$ versus $\log \left(\mathrm{C}_{\mathrm{e}}\right)$, and $C \mathrm{e} / q$ e versus $C$ e was the criteria by which the data fitted to Tempkin isotherm, Freundlich isotherm, and Langmuir isotherm, correspondingly.

From the linear plots, the values of $\mathrm{Q}_{\mathrm{o}}, \mathrm{K}_{\mathrm{L}}, \mathrm{K}_{\mathrm{F}}, 1 / \mathrm{n}, \mathrm{K}_{\mathrm{T}}, \mathrm{B}$, and $\mathrm{R}^{2}$ were determined from Figure 5 and recorded in Table 1. The results in Table 1 demonstrate that CR adsorption on $\mathrm{K}$ and $\mathrm{UL}$ adsorbents tracks the Freundlich isothermal model, where the $\mathrm{R}^{2}$ value is the highest. Therefore, multilayer adsorption of CR molecules occurs at the hotspots of the nano adsorbent surfaces, where heterogeneous sites of different adsorption energies and interaction between adsorbed molecules are unequally accessible. At $25^{\circ} \mathrm{C}$, the obtained $\mathrm{R}^{2}$ values by the Freundlich isotherms were 0.9942 and 0.9978 for K and UL adsorbents, respectively. In the adsorption process of CR on K and UL, the $1 / \mathrm{n}$ values for Freundlich isotherm are less than unity. This means that the adsorption process is favored, and the surface is heterogeneous with a lower interaction rate between the adsorbed CR molecules. Also, it implies that the CR adsorption mechanisms are multi-molecular and multi-anchorage adsorption [88, 89].

The modification of $\mathrm{K}$ with UL to form the KUL nanocomposite altered the adsorption isotherm mechanism of CR onto KUL and was found to follow the Langmuir isotherms. Therefore, the CR dye elimination occurs at the active sites of the KUL adsorbents on a single surface layer, and the adsorbed CR molecules do not interact with each other. At $25{ }^{\circ} \mathrm{C}$, the $\mathrm{R}^{2}$ value calculated by the Langmuir isotherms of KUL adsorbent was 0.9858 . The value of $\mathrm{R}_{\mathrm{L}}$ is $<1$, which means that CR adsorption is preferred in the study case [90]. 


\subsection{Adsorption kinetic models.}

In order to study the most suitable adsorption kinetic model, the CR adsorption on $\mathrm{K}$, UL, and KUL at various initial CR concentrations was addressed. The first-order, second-order, and Elovich kinetics linear graphs were represented in Figures 6 by plotting $\ln \left(\mathrm{q}_{\mathrm{e}}-\mathrm{q}_{\mathrm{t}}\right)$ versus $\mathrm{t}, \frac{\mathrm{t}}{\mathrm{q}_{\mathrm{t}}}$ versus $\mathrm{t}$, and $\mathrm{q}_{\mathrm{t}}$ versus $\ln (\mathrm{t})$, respectively. The adsorption kinetics parameters $\mathrm{k}_{1}, \mathrm{k}_{2}, \mathrm{q}_{\mathrm{e}}, \beta$, and $\alpha$ of the evaluation model in addition to $\mathrm{R}^{2}$ were obtained using the linear plots and depicted in Table 2.
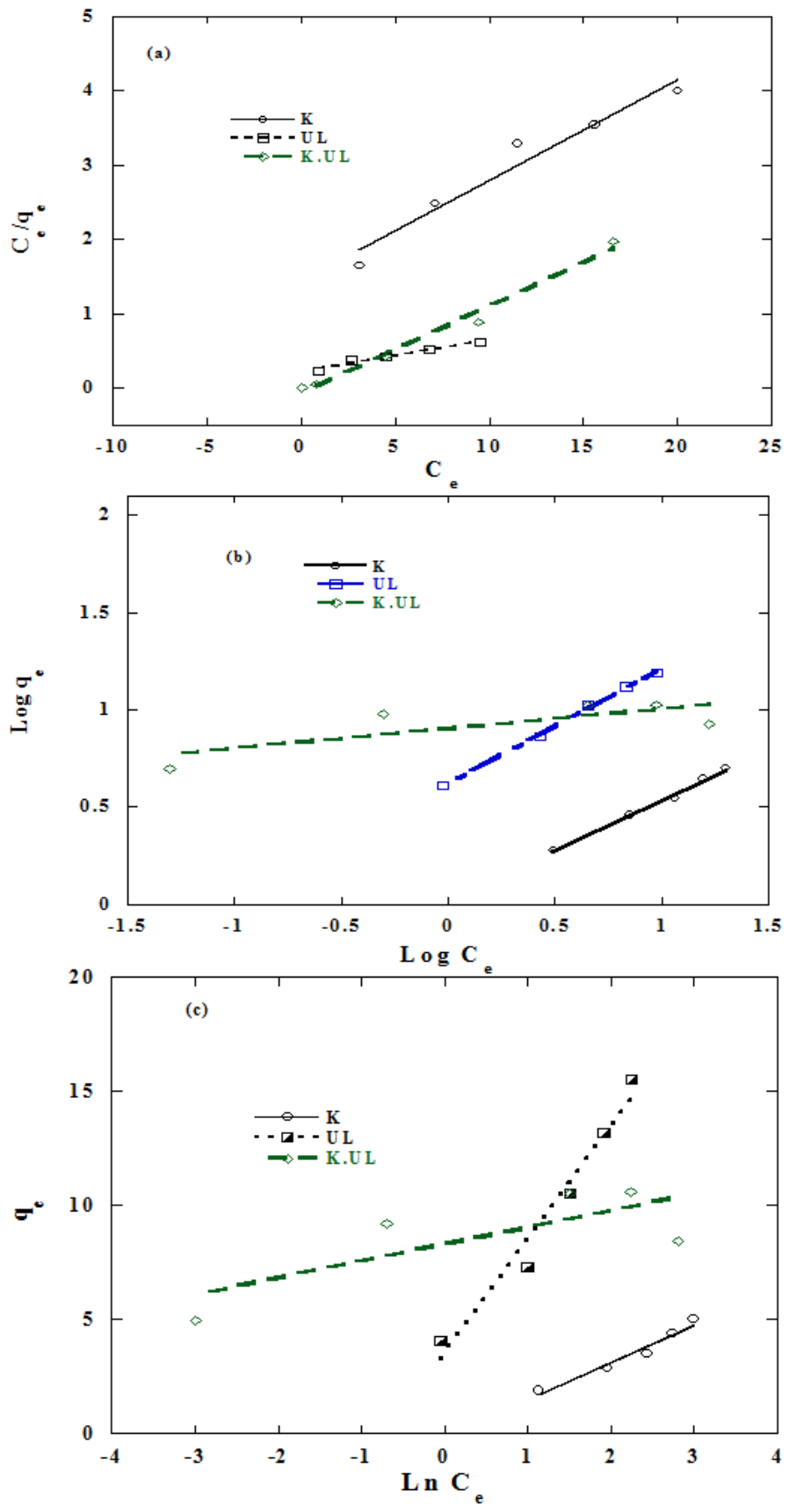

Figure 5. Plots of (a) Langmuir, (b) Freundlich, and (c) Temkin adsorption isotherms for the adsorption of CR dye by $50 \mathrm{mg}$ of $\mathrm{K}$, UL, and KUL at $25^{\circ} \mathrm{C}$ and initial $\mathrm{pH} 7$.

The linear fit and regression coefficient values of all the research kinetic models in , Table 2, confirm that the use of the second-order diffusion model can well handle the CR adsorption on $\mathrm{K}$ before the dye concentration of $10 \mathrm{ppm}$, and over this concentration, the adsorption process follows the first-order rate law, and this was also confirmed from the good 
approximation between the calculated qe and experimental qe. The CR adsorption onto KUL is well handled with the first-order diffusion model, and this appears in the higher $\mathrm{R}^{2}$ values and the very close values of the calculated qe and experimental qe. The CR adsorption onto UL follows two different kinetics adsorption models depending on the CR concentration where it follows the Elovich kinetics up to $10 \mathrm{ppm}$ concentration, and above this concentration, it follows the first-order diffusion model.
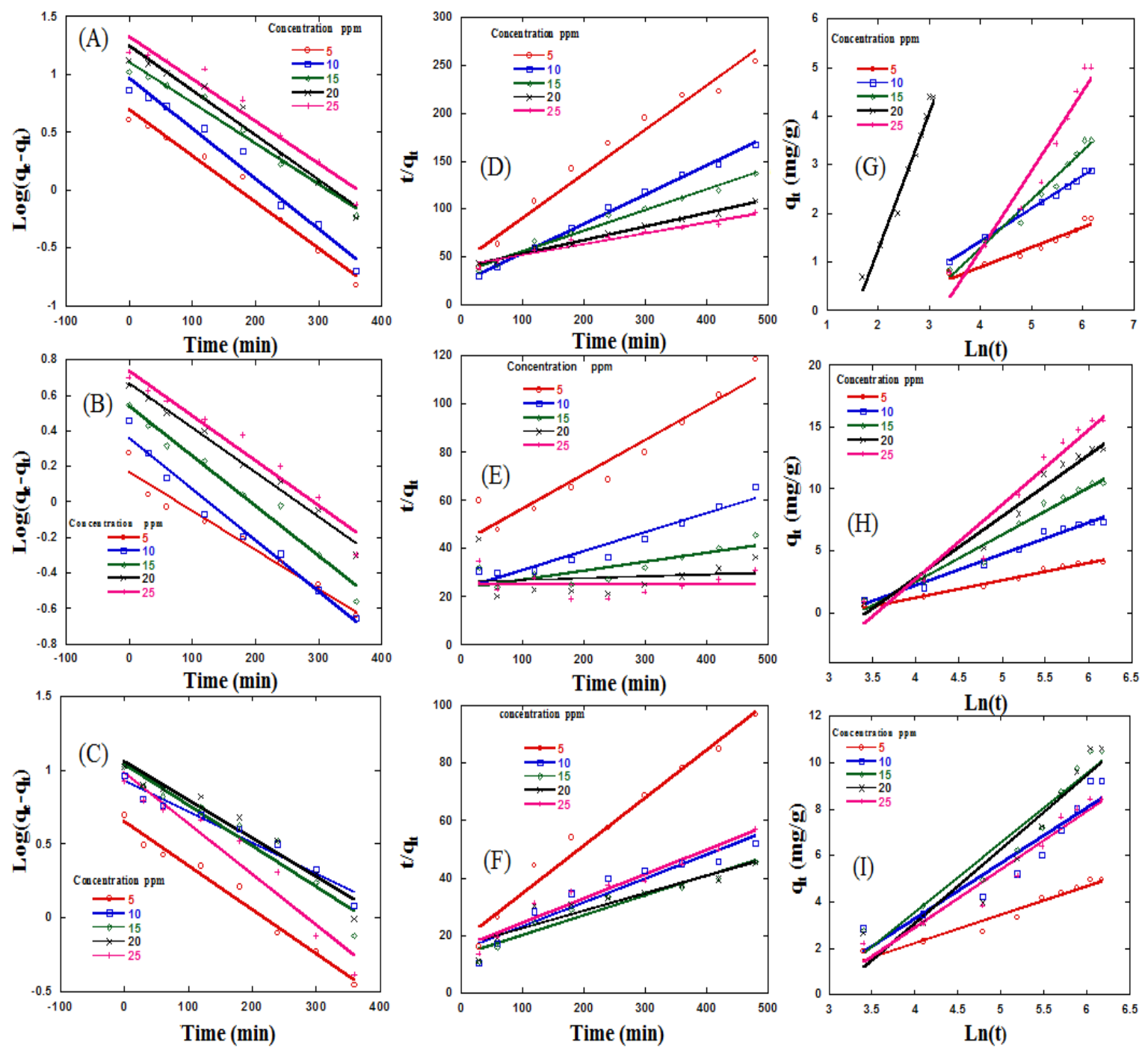

Figure 6. (A-C) Pseudo-first-order, (D-F) Pseudo-second-order, and (G-I) Elovich sorption kinetics of CR dye at $25^{\circ} \mathrm{C}$ and $\mathrm{pH} 7$ by $20 \mathrm{mg}$ of $\mathrm{K}$, UL, and KUL, respectively.

\subsection{Sorption mechanisms.}

To comprehend the adsorption kinetics process and rate-controlling steps, the practical data are fitted for Weber's Intra-particle diffusion. A straight line in the $q_{t}$ versus $t^{1 / 2}$ chart, Figure S2 (Supplementary data), suggests the applicability of the intra-particle diffusion model. The values of the rate constant of the intra-particle propagation model $\left(K_{3}\right)$ and boundary thickness constant (I), Table 3, are obtained using the slope and intercept of the linear fitting of Figure $\mathrm{S} 2$, respectively. The intercept $\mathrm{I} \neq 0$ indicates that the intra-particle diffusion model may not be the only rate control method for estimating the kinetics of the adsorption reaction [91]. The intercept in Figure S2 refers to the boundary layer effect. The larger intercept, the greater the contribution of surface adsorption in the rate control stage [91]. 
Table 2. Parameters of the kinetic models for CR dye adsorption on K, UL, and KUL.

\begin{tabular}{|c|c|c|c|c|c|c|c|c|c|c|c|c|}
\hline \multirow[t]{2}{*}{ Catalyst } & \multirow{2}{*}{$\begin{array}{c}\text { Conc, } \\
\text { ppm }\end{array}$} & \multicolumn{4}{|c|}{ First-order } & \multicolumn{4}{|c|}{ Second-order } & \multicolumn{3}{|c|}{ Elovich kinetic model } \\
\hline & & $\begin{array}{c}q_{e} \\
\exp \end{array}$ & qe calc. & $\mathbf{k}_{1}$ & $\mathbf{R}^{2}$ & $\underset{\exp }{\mathrm{q}_{\mathrm{e}}}$ & qe calc. & $\mathbf{k}_{2}$ & $\mathbf{R}^{2}$ & $\beta(g / m g)$ & $\begin{array}{c}\alpha \\
(\mathrm{mg} / \mathrm{min})\end{array}$ & $\mathbf{R}^{2}$ \\
\hline \multirow[b]{5}{*}{5} & 25 & 15.5 & 21.08 & 0.00365 & .9531 & 15.5 & 49.43 & $2.9682 \mathrm{E}-08$ & .0006 & 556 & 0.174707 & 0.9422 \\
\hline & 20 & 13.2 & 17.37801 & 0.0038 & 0.9699 & 13.2 & 87 & $2.2630 \mathrm{E}-06$ & 34 & 20040 & 32 & 0.9694 \\
\hline & 15 & 10.5 & 12.58925 & 0.0035 & 0.9793 & 10.5 & & $5.7003 \mathrm{E}-05$ & 0.6601 & 0.26178 & .134268 & 0.9674 \\
\hline & 10 & 7.3 & 9.276839 & 0.0043 & 0.9751 & 7.3 & 12.70 & 0.000267 & 0.9244 & 0.39683 & 0.107474 & 0.9781 \\
\hline & 5 & 4.05 & 4.946523 & 0.00399 & 0.9801 & 4.1 & & 0.000475 & 0.9194 & 0.72098 & 0.061133 & 0.9862 \\
\hline \multirow[b]{5}{*}{$\underline{y}$} & 25 & 5.0 & 5.48277 & 0.00253 & 0.9590 & 5.0 & & 0.0003234 & 0.9571 & 0.61805 & 0.064247 & 0.9443 \\
\hline & 20 & 4.4 & 4.650504 & 0.00251 & 0.9890 & 4. & & 0.0005128 & 0.9884 & 5461 & 0.596632 & 0.9773 \\
\hline & 15 & 3.5 & 2232 & 0.00281 & 0.9841 & 3. & 3 & 0.0013406 & 0.9804 & 7705 & 0.06594 & 0.9741 \\
\hline & 10 & 2.87 & 2.280867 & 0.00288 & 0.9778 & 2.9 & 3.30 & 0.0038700 & 0.9952 & 1.48898 & 0.102878 & 0.9948 \\
\hline & 5 & 1.88 & 1.473669 & 0.00219 & 0.9656 & 1.9 & 2.17 & 0.0047506 & 0.9660 & 1.23077 & 0.33412 & 0.9316 \\
\hline \multirow{5}{*}{$\underline{\underline{s}}$} & 25 & 8.4 & 9.594006 & 0.0034 & 0.9499 & 8.4 & 11.85 & 0.0004480 & 0.9463 & 0.40161 & 0.149724 & 0.9366 \\
\hline & 20 & 10.58 & 11.22018 & 0.00258 & & 10. & & & & & 0.15439 & 0.9009 \\
\hline & 15 & 10.5 & 10.96478 & 0.00277 & 0.9423 & 10.5 & 14.49 & 0.000 & 0.9412 & 445 & 0.180731 & 0.9327 \\
\hline & 10 & 9.2 & 8.542795 & 0.00211 & 0.9545 & 9.2 & 12.05 & 0.0004655 & 0.9072 & 0.41859 & 0.17314 & 0.8883 \\
\hline & 5 & 4.95 & 4.5196 & 0.00299 & 0.9777 & 5.0 & 6.02 & 0.0015224 & 0.9753 & 0.82305 & 0.140628 & 0.9467 \\
\hline
\end{tabular}

Table 3. Intra-particle diffusion constants for different initial CR concentrations at $25^{\circ} \mathrm{C}$.

\begin{tabular}{|c|c|c|c|c|}
\hline \multirow[t]{2}{*}{ Catalyst } & \multirow[t]{2}{*}{ Conc, ppm } & \multicolumn{3}{|c|}{ Intraparticle diffusion kinetic model } \\
\hline & & I & $\mathbf{k}_{\mathbf{3}}\left(\mathrm{mg} / \mathrm{g} \min ^{1 / 2}\right)$ & $\mathbf{R}^{2}$ \\
\hline \multirow[b]{5}{*}{ S } & $25 \mathrm{ppm}$ & -2.4725 & 0.8649 & 0.9341 \\
\hline & $20 \mathrm{ppm}$ & -1.6655 & 0.7259 & 0.9494 \\
\hline & $15 \mathrm{ppm}$ & -1.0904 & 0.5662 & 0.9545 \\
\hline & $10 \mathrm{ppm}$ & -0.4043 & 0.3877 & 0.9570 \\
\hline & $5 \mathrm{ppm}$ & 0.218 & 0.2128 & 0.9660 \\
\hline \multirow[b]{5}{*}{ 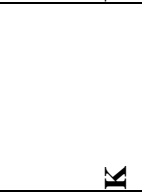 } & $25 \mathrm{ppm}$ & -0.4224 & 0.2499 & 0.9824 \\
\hline & $20 \mathrm{ppm}$ & -0.2498 & 0.2201 & 0.9878 \\
\hline & $15 \mathrm{ppm}$ & 0.02811 & 0.1666 & 0.9924 \\
\hline & $10 \mathrm{ppm}$ & 0.3298 & 0.1272 & 0.9986 \\
\hline & $5 \mathrm{ppm}$ & 0.1953 & 0.0799 & 0.9700 \\
\hline \multirow{5}{*}{ 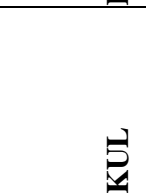 } & $25 \mathrm{ppm}$ & -0.1236 & 0.4122 & 0.9844 \\
\hline & $20 \mathrm{ppm}$ & -0.5605 & 0.5142 & 0.9781 \\
\hline & $15 \mathrm{ppm}$ & -0.1428 & 0.4996 & 0.9912 \\
\hline & $10 \mathrm{ppm}$ & 0.0527 & 0.4153 & 0.9838 \\
\hline & $5 \mathrm{ppm}$ & 0.3644 & 0.2244 & 0.9791 \\
\hline
\end{tabular}

3.6. Field experiments and Comparison of Adsorption Capability of K, UL, and KUL.

The optimized parameters for the newly synthesized KUL nano adsorbent were $0.02 \mathrm{~g}$ adsorbent mass, near room temperature, and contact time of $420 \mathrm{~min}$, while the $\mathrm{pH}$ of the wastewater containing the waste dye remained unchanged. The presence of different wavelengths corresponding to different dyes was detected by the optical scanning of the asreceived industrial wastewater using UV/Vis Perkin Elmer spectrophotometer (lambda 950). Absorbance at various wavelengths is recorded after 420 min contact time to measure the removal efficiency of dyes from industrial wastewater. At various wavelengths, the data revealed removal efficiency ranging from $85 \%$ to $94 \%$.

Table S3 (Supplementary data) compares the optimized conditions, removal\%, and adsorption capacity, qm, of our studied K, UL, and KUL nano adsorbents for CR dye removal to those previously recorded for various adsorbents in literature [34, 41, 42, 92-95]. As shown in Table S3, our optimized KUL nano adsorbent showed high performance relative to most of the previously reported K and/or UL-based adsorbents.

\section{Conclusions}

From the hydrothermal treatment of kaolinite (K) and alga(UL), a novel alga/kaolinite (KUL) nanocomposite KUL was prepared and used as a new aqueous solution adsorbent for 
CR. The morphologies and structures of K, UL, and KUL have been investigated to show the agglomeration of UL nanoparticles and kaolinite nanopores to form nanocomposite crystallites of $40.3 \mathrm{~nm}$ size. The adsorption studies of CR dye showed $99 \%, 81 \%$, and $37.7 \%$ removal\% of $5 \mathrm{ppm} \mathrm{CR}$ dye using KUL, UL, and $\mathrm{K}$ in order. The order of the performance is turned to UL $>\mathrm{KUL}>\mathrm{K}$ for $\mathrm{CR}$ concentration $\geq 20 \mathrm{ppm}$. Also, the $\mathrm{CR}$ removal $\%$ is highly affected by adsorbent mass, adsorption temperature, and $\mathrm{pH}$ value. By increasing the $\mathrm{K}$, UL, and KUL dosage from 0.01 to $0.02 \mathrm{~g}$, the removal\% is increased and then decreased. The best temperature for CR adsorption onto KUL is $40^{\circ} \mathrm{C}$ at $\mathrm{pH}>7$. The reusability test for $\mathrm{K}$, UL, and KUL showed that any adsorbents were not preferred for CR removal reuse. The CR adsorption isotherms and kinetics on K, UL, and KUL indicate that the Freundlich isothermal models are monitored by $\mathrm{K}$ and UL adsorbents, while KUL is better suited to Langmuir isotherms. With the first-order diffusion model, CR adsorption on KUL is well controlled, while K and UL adopt two separate models of kinetic adsorption depending on the concentration of CR. Finally, field tests showed surprising results of $91 \%$ dye removal efficiency from industrial wastewater, which confirms the foundation of a modern eco-friendly catalysis device that could assist in the reuse of industrial wastewater.

\section{Funding}

This research received no external funding.

\section{Acknowledgments}

This research has no acknowledgment.

\section{Conflicts of Interest}

The authors declare no conflict of interest.

\section{References}

1. Guizellini, F.C.; Franzin, B.T.; da Silva, M.A.; Abra, L.M.; Hojo, O.; Pastre, I.A.; Ribeiro, C.A.; PaivaSantos, C.D.O.; Fertonani, F.L. Thermal, morphostructural and spectrometric characterization of an antibacterial kaolinite-based filter modified with silver for water treatment. J Therm Anal Calorim 2021, 143, 47-60, https://doi.org/10.1007/s10973-020-09267-w.

2. Dutta, S.; Gupta, B.; Srivastava, S.K.; Gupta, A.K. Recent advances on the removal of dyes from wastewater using various adsorbents: a critical review. Mater Adv 2021, 2, 4497-4531, https://doi.org/10.1039/d1ma00354b.

3. Nizam, N.U.M.; Hanafiah, M.M.; Mahmoudi, E.; Halim, A.A.; Mohammad, A.W. The removal of anionic and cationic dyes from an aqueous solution using biomass-based activated carbon. Sci Rep 2021, 11, https://doi.org/10.1038/s41598-021-88084-z.

4. Soliman, N.; Mohamed, H.S.; Elsayed, R.H.; Elmedny, N.M.; Elghandour, A.H.; Ahmed, S.A. Removal of chromium an2020,d cadmium ions from aqueous solution using residue of Rumex dentatus L. plant waste. Desalin Water Treat 2019, 149, 181-193.

5. Shaban, M.; Abukhadra, M.R.; Hamd, A.; Amin, R.R.; Abdel Khalek, A. Photocatalytic removal of Congo red dye using MCM-48/Ni2O3 composite synthesized based on silica gel extracted from rice husk ash; fabrication and application. J Environ Manage 2017, 204, 189-199, https://doi.org/10.1016/j.jenvman.2017.08.048.

6. Soliman, N.K.; Mohamed, H.S.; Ahmed, S.A.; Sayed, F.H.; Elghandour, A.H.; Ahmed, S.A. Cd2+ and Cu2+ removal by the waste of the marine brown macroalga Hydroclathrus clathratus. J Environ Technol Innov 2019, 15, https://doi.org/10.1016/j.eti.2019.100365.

7. Soliman, N.K.; Moustafa, A.F. Industrial solid waste for heavy metals adsorption features and challenges; a review. J Mater Res Technol 2020, 9, 10235-10253, https://doi.org/10.1016/j.jmrt.2020.07.045.

8. Da'na, E. Adsorption of heavy metals on functionalized-mesoporous silica: A review. Micropor Mesopor Mat 2017, 247, 145-157, https://doi.org/10.1016/j.micromeso.2017.03.050. 
9. Anderson, K.; Ryan, B.; Sonntag, W.; Kavvada, A.; Friedl, L. Earth observation in service of the 2030 Agenda for Sustainable Development. Geo-spatial Information Science 2017, 20, 77-96, https://doi.org/10.1080/10095020.2017.1333230.

10. Gopal, R.A.; Song, M.; Yang, D.; Lkhagvaa, T.; Chandrasekaran, S.; Choi, D. Synthesis of hierarchically structured $\gamma$-Fe2O3-PPy nanocomposite as effective adsorbent for cationic dye removal from wastewater. Environm Pollut 2020, 267, https://doi.org/10.1016/j.envpol.2020.115498.

11. Combes, R.D.; Haveland-Smith, R.B. A review of the genotoxicity of food, drug and cosmetic colours and other azo, triphenylmethane and xanthene dyes. Mutat Res 1982, 98, 101-248, https://doi.org/10.1016/01651110(82)90015-X.

12. Bae, J.-S.; Freeman, H.S. Aquatic toxicity evaluation of new direct dyes to the Daphnia magna. Dyes Pigments 2007, 73, 81-85, https://doi.org/10.1016/j.dyepig.2005.10.015.

13. Dadfarnia, S.; Haji Shabani, A.M.; Moradi, S.E.; Emami, S. Methyl red removal from water by iron based metal-organic frameworks loaded onto iron oxide nanoparticle adsorbent. Appl Surf Sci 2015, 330, 85-93, https://doi.org/10.1016/j.apsusc.2014.12.196.

14. Chowdhury, M.F.; Khandaker, S.; Sarker, F.; Islam, A.; Rahman, M.T.; Awual, M.R. Current treatment technologies and mechanisms for removal of indigo carmine dyes from wastewater: A review. J Mol Liq 2020, 318, https://doi.org/10.1016/j.molliq.2020.114061.

15. Lin, H.; Gao, W.; Meng, F.; Liao, B.-Q.; Leung, K.-T.; Zhao, L.; Chen, J.; Hong, H. Membrane Bioreactors for Industrial Wastewater Treatment: A Critical Review. Crit Rev Env Sci Tec 2012, 42, 677-740, https://doi.org/10.1080/10643389.2010.526494.

16. Oller, I.; Malato, S.; Sánchez-Pérez, J.A. Combination of Advanced Oxidation Processes and biological treatments for wastewater decontamination-A review. Sci Total Environ 2011, 409, 4141-4166, https://doi.org/10.1016/j.scitotenv.2010.08.061.

17. Gupta, V.K.; Suhas. Application of low-cost adsorbents for dye removal - A review. J Environ Manage 2009 , 90, 2313-2342, https://doi.org/10.1016/j.jenvman.2008.11.017.

18. Kant, R. Textile dyeing industry an environmental hazard. Nat Sci 2012, 4, 22-26, https://doi.org/10.4236/ns.2012.41004.

19. Mohamed, H.S.; Soliman, N.K.; Moustafa, A.F.; Abdel-Gawad, O.F.; Taha, R.R.; Ahmed, S.A. Nano metal oxide impregnated Chitosan-4-nitroacetophenone for industrial dye removal. Int J Environ An Ch 2019, 128, https://doi.org/10.1080/03067319.2019.1691178.

20. Yagub, M.T.; Sen, T.K.; Afroze, S.; Ang, H.M. Dye and its removal from aqueous solution by adsorption: A review. Adv Colloid Interfac 2014, 209, 172-184, https://doi.org/10.1016/j.cis.2014.04.002.

21. Rahimian, R.; Zarinabadi, S. A review of studies on the removal of methylene blue dye from industrial wastewater using activated carbon adsorbents made from almond bark. Progress in Chemical and Biochemical Research 2020, 3, 251-268..

22. Foroughi-Dahr, M.; Abolghasemi, H.; Esmaili, M.; Shojamoradi, A.; Fatoorehchi, H. Adsorption Characteristics of Congo Red from Aqueous Solution onto Tea Waste. Chem Eng Commun 2015, 202, 181193, https://doi.org/10.1080/00986445.2013.836633.

23. Shaban, M.; Abukhadra, M.R.; Hamd, A. Recycling of glass in synthesis of MCM-48 mesoporous silica as catalyst support for Ni2O3 photocatalyst for Congo red dye removal. Clean Technol Envir 2018, 20, 13-28, https://doi.org/10.1007/s10098-017-1447-5.

24. Shaban, M.; AbdAllah, H.; Said, L.; Ahmed, A.M. Water desalination and dyes separation from industrial wastewater by PES/TiO2NTs mixed matrix membranes. $J$ Polym Res 2019, 26, https://doi.org/10.1007/s10965-019-1831-4.

25. Shaban, M.; Elwahab, F.A.; Ghitas, A.E.; El Zayat, M.Y. Efficient and recyclable photocatalytic degradation of methylene blue dye in aqueous solutions using nanostructured $\mathrm{Cd} 1-\mathrm{xCoxS}$ films of different doping levels. J Sol-Gel Sci Techn 2020, 95, 276-288, https://doi.org/10.1007/s10971-020-05331-x.

26. Abukhadra, M.R.; Mohamed, A.S. Adsorption Removal of Safranin Dye Contaminants from Water Using Various Types of Natural Zeolite. Silicon 2019, 11, 1635-1647, https://doi.org/10.1007/s12633-018-9980-3.

27. Yin, X.; Zhang, Z.; Ma, H.; Venkateswaran, S.; Hsiao, B.S. Ultra-fine electrospun nanofibrous membranes for multicomponent wastewater treatment: Filtration and adsorption. Sep Purif Technol 2020, 242, https://doi.org/10.1016/j.seppur.2020.116794.

28. Ghaedi, M.; Shokrollahi, A.; Tavallali, H.; Shojaiepoor, F.; Keshavarz, B.; Hossainian, H.; Soylak, M.; Purkait, M.K. Activated carbon and multiwalled carbon nanotubes as efficient adsorbents for removal of arsenazo(III) and methyl red from waste water. Toxicol Environ Chem 2011, 93, 438-449, https://doi.org/10.1080/02772248.2010.540244.

29. Anjaneyulu, Y.; Sreedhara Chary, N.; Samuel Suman Raj, D. Decolourization of Industrial Effluents Available Methods and Emerging Technologies - A Review. Rev Environ Sci Bio 2005, 4, 245-273, https://doi.org/10.1007/s11157-005-1246-z.

30. Özcan, A.; Ömeroğlu, Ç.; Erdoğan, Y.; Özcan, A.S. Modification of bentonite with a cationic surfactant: An adsorption study of textile dye Reactive Blue 19. J Hazard Mater 2007, 140, 173-179, https://doi.org/10.1016/j.jhazmat.2006.06.138. 
31. El Qada, E.N.; Allen, S.J.; Walker, G.M. Adsorption of Methylene Blue onto activated carbon produced from steam activated bituminous coal: A study of equilibrium adsorption isotherm. Chem Eng J 2006, 124, 103110, https://doi.org/10.1016/j.cej.2006.08.015.

32. Doğan, M.; Alkan, M.; Demirbaş, Ö.; Özdemir, Y.; Özmetin, C. Adsorption kinetics of maxilon blue GRL onto sepiolite from aqueous solutions. Chem Eng J 2006, 124, 89-101, https://doi.org/10.1016/j.cej.2006.08.016.

33. Fei, F.; Gao, Z.; Wu, H.; Wurendaodi, W.; Zhao, S.; Asuha, S. Facile solid-state synthesis of Fe3O4/kaolinite nanocomposites for enhanced dye adsorption. J Solid State Chem 2020, 291, https://doi.org/10.1016/j.jssc.2020.121655.

34. Shaban, M.; Sayed, M.I.; Shahien, M.G.; Abukhadra, M.R.; Ahmed, Z.M. Adsorption behavior of inorganicand organic-modified kaolinite for Congo red dye from water, kinetic modeling, and equilibrium studies. $J$ Sol-Gel Sci Techn 2018, 87, 427-441, https://doi.org/10.1007/s10971-018-4719-6.

35. Zayed, M.; Ahmed, A.M.; Shaban, M. Synthesis and characterization of nanoporous $\mathrm{ZnO}$ and $\mathrm{Pt} / \mathrm{ZnO}$ thin films for dye degradation and water splitting applications. Int J Hydrogen Energ 2019, 44, 17630-17648, https://doi.org/10.1016/j.ijhydene.2019.05.117.

36. Daneshvar, E.; Vazirzadeh, A.; Niazi, A.; Kousha, M.; Naushad, M.; Bhatnagar, A. Desorption of Methylene blue dye from brown macroalga: Effects of operating parameters, isotherm study and kinetic modeling. $J$ Clean Prod 2017, 152, 443-453, https://doi.org/10.1016/j.jclepro.2017.03.119.

37. Avila, R.; Peris, A.; Eljarrat, E.; Vicent, T.; Blánquez, P. Biodegradation of hydrophobic pesticides by microalgae: Transformation products and impact on algae biochemical methane potential. Sci Total Environ 2021, 754, https://doi.org/10.1016/j.scitotenv.2020.142114.

38. Marzbali, M.H.; Mir, A.A.; Pazoki, M.; Pourjamshidian, R.; Tabeshnia, M. Removal of direct yellow 12 from aqueous solution by adsorption onto spirulina algae as a high-efficiency adsorbent. J Environ Chem Eng 2017, 5, 1946-1956, https://doi.org/10.1016/j.jece.2017.03.018.

39. Wernert, V.; Schaef, O.; Aloui, L.; Chassigneux, C.; Ayari, F.; Ben Hassen Chehimi, D.; Denoyel, R. Cancrinite synthesis from natural kaolinite by high pressure hydrothermal method: Application to the removal of $\mathrm{Cd} 2+$ and $\mathrm{Pb} 2+$ from water. Micropor Mesopor Mat 2020, 301, https://doi.org/10.1016/j.micromeso.2020.110209.

40. Lee, S.O.; Tran, T.; Jung, B.H.; Kim, S.J.; Kim, M.J. Dissolution of iron oxide using oxalic acid. Hydrometallurgy 2007, 87, 91-99, https://doi.org/10.1016/j.hydromet.2007.02.005.

41. Ayanda, O.S.; Sodeinde, K.O.; Okolo, P.; Ajayi, A.A.; Nelana, S.M.; Naidoo, E.B. Adsorptive Behavior of Kaolin for Amido Black Dye in Aqueous Solution. Orient J Chem 2018, 34, 1233-9, https://doi.org/10.13005/ojc/340305.

42. Vimonses, V.; Lei, S.; Jin, B.; Chow, C.W.K.; Saint, C. Kinetic study and equilibrium isotherm analysis of Congo Red adsorption by clay materials. Chem Eng J 2009, 148, 354-364, https://doi.org/10.1016/j.cej.2008.09.009.

43. Leonel, E.; Nassar, E.; Ciuffi, K.; Dos Reis, M.; Calefi, P. Effect of high-energy ball milling in the structural and textural properties of kaolinite. Cerâmica 2014, 60, 267-272, https://doi.org/10.1590/S036669132014000200016.

44. Abukhadra, M.R.; El-Meligy, M.A.; El-Sherbeeny, A.M. Evaluation and characterization of Egyptian ferruginous kaolinite as adsorbent and heterogeneous catalyst for effective removal of safranin-O cationic dye from water. Arab J Geosci 2020, 13, https://doi.org/10.1007/s12517-020-5182-6.

45. Hasan, A.K.M.M.; Dey, S.C.; Rahman, M.M.; Zakaria, A.M.; Sarker, M.; Ashaduzzaman, M.D.; Shamsuddin, S.M.D. A kaolinite/ $/ \mathrm{TiO}_{2} / \mathrm{ZnO}$-based novel ternary composite for photocatalytic degradation of anionic azo dyes. B Mater Sci 2019, 43, https://doi.org/10.1007/s12034-019-1964-4.

46. Ming, H. Modification of kaolinite by controlled hydrothermal deuteration-a DRIFT spectroscopic study. Clay Miner 2004, 39, 349-362, https://doi.org/10.1180/0009855043930140.

47. Awwad, A.; Amer, M.; Al-aqarbeh, M. TiO2-kaolinite nanocomposite prepared from the Jordanian Kaolin clay: Adsorption and thermodynamics of $\mathrm{Pb}$ (II) and $\mathrm{Cd}$ (II) ions in aqueous solution. Chem. Int. 2020, 6, 168-178, https://doi.org/10.5281/zenodo.3597558.

48. Khedr, M.H.; Abdel Halim, K.S.; Soliman, N.K. Effect of temperature on the kinetics of acetylene decomposition over reduced iron oxide catalyst for the production of carbon nanotubes. Appl Surf Sci 2008, 255, 2375-2381, https://doi.org/10.1016/j.apsusc.2008.07.096.

49. Khedra, M.; Nasrb, M.; Halimb, K.; Farghalia, A.; Solimanc, N. Catalytic decomposition of hydrocarbon gas over various nanostructured metal oxides for hydrocarbon removal and production of carbon nanotubes. Int. J. Eng. Res. Gen. Sci 2014, 2.

50. Holzwarth, U.; Gibson, N. The Scherrer equation versus the 'Debye-Scherrer equation'. Nat Nanotechnol 2011, 6, 534-534, https://doi.org/10.1038/nnano.2011.145.

51. Khedr, M.H.; Abdel Halim, K.S.; Soliman, N.K. Synthesis and photocatalytic activity of nano-sized iron oxides. Mater Lett 2009, 63, 598-601, https://doi.org/10.1016/j.matlet.2008.11.050.

52. Langmuir, I. The Adsorption Of Gases On Plane Surfaces Of Glass, Mica And Platinum. J Am Chem Soc 1918, 40, 1361-1403, https://doi.org/10.1021/ja02242a004.

53. Freundlich, H. Over the adsorption in solution. J. Phys. chem 1906, 57, 1100-1107. 
54. Mohamed, F.; Abukhadra, M.R.; Shaban, M. Removal of safranin dye from water using polypyrrole nanofiber/Zn-Fe layered double hydroxide nanocomposite (Ppy NF/Zn-Fe LDH) of enhanced adsorption and photocatalytic properties. Sci Total Environ 2018, 640-641, 352-363, https://doi.org/10.1016/j.scitotenv.2018.05.316.

55. Temkin, M. Kinetics of ammonia synthesis on promoted iron catalysts. Acta physiochim. URSS 1940, 12, 327-356.

56. Ozdemir, O.; Armagan, B.; Turan, M.; Çelik, M.S. Comparison of the adsorption characteristics of azoreactive dyes on mezoporous minerals. Dyes Pigments 2004, 62, 49-60, https://doi.org/10.1016/j.dyepig.2003.11.007.

57. Xin, N.; Gu, X.; Wu, H.; Hu, Y.; Yang, Z. Application of genetic algorithm-support vector regression (GASVR) for quantitative analysis of herbal medicines. J Chemometr 2012, 26, 353-360, https://doi.org/10.1002/cem.2435.

58. Fan, L.; Luo, C.; Sun, M.; Qiu, H.; Li, X. Synthesis of magnetic $\beta$-cyclodextrin-chitosan/graphene oxide as nanoadsorbent and its application in dye adsorption and removal. Colloid Surface B 2013, 103, 601-607, https://doi.org/10.1016/j.colsurfb.2012.11.023.

59. Demiral, H.; Gündüzoğlu, G. Removal of nitrate from aqueous solutions by activated carbon prepared from sugar beet bagasse. Bioresource Technol 2010, 101, 1675-1680, https://doi.org/10.1016/j.biortech.2009.09.087.

60. Wu, F.-C.; Tseng, R.-L.; Juang, R.-S. Initial behavior of intraparticle diffusion model used in the description of adsorption kinetics. Chem Eng J 2009, 153, 1-8, https://doi.org/10.1016/j.cej.2009.04.042.

61. Frost, R.L.; Horváth, E.; Makó, É.; Kristóf, J. Modification of low- and high-defect kaolinite surfaces: implications for kaolinite mineral processing. $J$ Colloid Interf Sci 2004, 270, 337-346, https://doi.org/10.1016/j.jcis.2003.10.034.

62. Pi, Z.; Liu, Z.; Yang, C.; Tian, X.; Fei, J.; Zheng, J. Exfoliation of kaolinite by urea-intercalation precursor and microwave irradiation assistance process. Frontiers of Earth Science in China 2007, 1, 26-29, https://doi.org/10.1007/s11707-007-0004-7.

63. Vaculikova, L.; Plevova, E.; Vallova, S.; Koutnik, I. Characterization and differentiation of kaolinites from selected Czech deposits using infrared spectroscopy and differential thermal analysis. Acta Geodyn Geomater 2011, 8, 59-67

64. Horváth, E.; Kristóf, J.; Frost, R.L. Vibrational Spectroscopy of Intercalated Kaolinites. Part I. Appl Spectrosc Rev 2010, 45, 130-147, https://doi.org/10.1080/05704920903435862.

65. Madejová, J.; Komadel, P. Baseline studies of the Clay Miner society source clays: Infrared methods. Clays and Clay Miner 2001, 49, 410-432, https://doi.org/10.1346/ccmn.2001.0490508.

66. Masoudi, R.; Moghimi, H.; Azin, E.; Taheri, R.A. Adsorption of cadmium from aqueous solutions by novel Fe3O4- newly isolated Actinomucor sp. bio-nanoadsorbent: functional group study. Artif Cell Nanomed B 2018, 46, S1092-S1101, https://doi.org/10.1080/21691401.2018.1533841.

67. Nautiyal, P.; Subramanian, K.A.; Dastidar, M.G. Adsorptive removal of dye using biochar derived from residual algae after in-situ transesterification: Alternate use of waste of biodiesel industry. J Environ Manage 2016, 182, 187-197, https://doi.org/10.1016/j.jenvman.2016.07.063.

68. Ghoneim, M.M.; El-Desoky, H.S.; El-Moselhy, K.M.; Amer, A.; Abou El-Naga, E.H.; Mohamedein, L.I.; Al-Prol, A.E. Removal of cadmium from aqueous solution using marine green algae, Ulva lactuca. The Egyptian Journal of Aquatic Research 2014, 40, 235-242, https://doi.org/10.1016/j.ejar.2014.08.005.

69. Ibrahim, W.M.; Hassan, A.F.; Azab, Y.A. Biosorption of toxic heavy metals from aqueous solution by Ulva lactuca activated carbon. Egyptian Journal of Basic and Applied Sciences 2016, 3, 241-249, https://doi.org/10.1016/j.ejbas.2016.07.005.

70. Gougazeh, M.; Buhl, J.C. Geochemical and mineralogical characterization of the Jabal Al-Harad kaolin deposit, southern Jordan, for its possible utilization. Clay Miner 2010, 45, 301-314, https://doi.org/10.1180/claymin.2010.045.3.301.

71. Zhao, H.; Deng, Y.; Harsh, J.B.; Flury, M.; Boyle, J.S. Alteration of Kaolinite to Cancrinite and Sodalite by Simulated Hanford Tank Waste and its Impact on Cesium Retention. Clays and Clay Miner 2004, 52, 1-13, https://doi.org/10.1346/ccmn.2004.0520101.

72. Biscoe, J.; Warren, B.E. An X-Ray Study of Carbon Black. J Appl Phys 1942, 13, 364-371, https://doi.org/10.1063/1.1714879.

73. Zen, S.; El Berrichi, F.Z. Adsorption of tannery anionic dyes by modified kaolin from aqueous solution. Desalin Water Treat 2016, 57, 6024-6032, https://doi.org/10.1080/19443994.2014.981218.

74. Tehrani-Bagha, A.R.; Nikkar, H.; Mahmoodi, N.M.; Markazi, M.; Menger, F.M. The sorption of cationic dyes onto kaolin: Kinetic, isotherm and thermodynamic studies. Desalination 2011, 266, 274-280, https://doi.org/10.1016/j.desal.2010.08.036.

75. Mokhtar, N.; Aziz, E.A.; Aris, A.; Ishak, W.F.W.; Mohd Ali, N.S. Biosorption of azo-dye using marine macro-alga of Euchema Spinosum. J Environ Chem Eng 2017, 5, 5721-5731, https://doi.org/10.1016/j.jece.2017.10.043.

76. Sharma, Y.C.; Uma. Optimization of Parameters for Adsorption of Methylene Blue on a Low-Cost Activated Carbon. J Chem Eng Data 2010, 55, 435-439, https://doi.org/10.1021/je900408s. 
77. Asif Tahir, M.; Bhatti, H.N.; Iqbal, M. Solar Red and Brittle Blue direct dyes adsorption onto Eucalyptus angophoroides bark: Equilibrium, kinetics and thermodynamic studies. J Environ Chem Eng 2016, 4, 24312439, https://doi.org/10.1016/j.jece.2016.04.020.

78. Abukhadra, M.R.; Shaban, M. Recycling of different solid wastes in synthesis of high-order mesoporous silica as adsorbent for safranin dye. Int J Environ Sci Te 2019, 16, 7573-7582, https://doi.org/10.1007/s13762019-02231-8.

79. Pons, M.P.; Fusté, M.C. Uranium uptake by immobilized cells of Pseudomonas strain EPS 5028. Appl Microbiol Biot 1993, 39, 661-665, https://doi.org/10.1007/bf00205071.

80. Foo, K.Y.; Hameed, B.H. Preparation, characterization and evaluation of adsorptive properties of orange peel based activated carbon via microwave induced K2CO3 activation. Bioresource Technol 2012, 104, 679-686, https://doi.org/10.1016/j.biortech.2011.10.005.

81. Shaban, M.; Abukhadra, M.R.; Khan, A.A.P.; Jibali, B.M. Removal of Congo red, methylene blue and Cr(VI) ions from water using natural serpentine. $J$ Taiwan Inst Chem $E$ 2018, 82, 102-116, https://doi.org/10.1016/j.jtice.2017.10.023.

82. Ansari, R.; Mosayebzadeh, Z. Removal Of Eosin Y, An Anionic Dye, From Aqueous Solutions Using Conducting Electroactive Polymers. Iran Polym J (ENGLISH) 2010, 19, 541-551.

83. Doğan, M.; Alkan, M.; Türkyilmaz, A.; Özdemir, Y. Kinetics and mechanism of removal of methylene blue by adsorption onto perlite. J Hazard Mater 2004, 109, 141-148, https://doi.org/10.1016/j.jhazmat.2004.03.003.

84. Noreen, S.; Bhatti, H.N.; Zuber, M.; Zahid, M.; Asgher, M. Removal of Actacid Orange-RL Dye Using Biocomposites: Modeling Studies. Pol. J. Environ. Stud. 2017, 26, 2125-2134, https://doi.org/10.15244/pjoes/68446.

85. Mushtaq, M.; Bhatti, H.N.; Iqbal, M.; Noreen, S. Eriobotrya japonica seed biocomposite efficiency for copper adsorption: Isotherms, kinetics, thermodynamic and desorption studies. J Environ Manage 2016, 176, 21-33, https://doi.org/10.1016/j.jenvman.2016.03.013.

86. Rashid, A.; Bhatti, H.N.; Iqbal, M.; Noreen, S. Fungal biomass composite with bentonite efficiency for nickel and zinc adsorption: A mechanistic study. Ecol Eng 2016, 91, 459-471, https://doi.org/10.1016/j.ecoleng.2016.03.014.

87. Naghizadeh, A. Regeneration of Carbon Nanotubes Exhausted with Humic Acid Using Electro-Fenton Technology. Arab J Sci Eng 2016, 41, 155-161, https://doi.org/10.1007/s13369-015-1643-8.

88. Bagherifam, S.; Komarneni, S.; Lakzian, A.; Fotovat, A.; Khorasani, R.; Huang, W.; Ma, J.; Hong, S.; Cannon, F.S.; Wang, Y. Highly selective removal of nitrate and perchlorate by organoclay. Appl Clay Sci 2014, 95, 126-132, https://doi.org/10.1016/j.clay.2014.03.021.

89. Sellaoui, L.; Guedidi, H.; Knani, S.; Reinert, L.; Duclaux, L.; Ben Lamine, A. Application of statistical physics formalism to the modeling of adsorption isotherms of ibuprofen on activated carbon. Fluid Phase Equilibr 2015, 387, 103-110, https://doi.org/10.1016/j.fluid.2014.12.018.

90. Hall, K.R.; Eagleton, L.C.; Acrivos, A.; Vermeulen, T. Pore- and Solid-Diffusion Kinetics in Fixed-Bed Adsorption under Constant-Pattern Conditions. Industrial \& Engineering Chemistry Fundamentals 1966, 5 , 212-223, https://doi.org/10.1021/i160018a011.

91. Weber Walter, J.; Morris, J.C. Kinetics of Adsorption on Carbon from Solution. Journal of the Sanitary Engineering Division 1963, 89, 31-59, https://doi.org/10.1061/jsedai.0000430.

92. Zenasni, M.; Meroufel, B.; Merlin, A.; George, B. Adsorption of Congo red from aqueous solution using CTAB-kaolin from Bechar Algeria. Journal of surface engineered materials and advanced technology 2014, 4, 332-341, https://doi.org/10.4236/jsemat.2014.46037.

93. Tor, A.; Cengeloglu, Y. Removal of congo red from aqueous solution by adsorption onto acid activated red mud. J Hazard Mater 2006, 138, 409-415, https://doi.org/10.1016/j.jhazmat.2006.04.063.

94. Bhattacharyya, K.G.; Gupta, S.S.; Sarma, G.K. Kinetics, equilibrium isotherms and thermodynamics of adsorption of Congo red onto natural and acid-treated kaolinite and montmorillonite. Desalin Water Treat 2015, 53, 530-542, https://doi.org/10.1080/19443994.2013.839405.

95. Omer, O.S.; Hussein, B.H.M.; Ouf, A.M.; Hussein, M.A.; Mgaidi, A. An organified mixture of illite-kaolinite for the removal of Congo red from wastewater. Journal of Taibah University for Science 2018, 12, 858-866, https://doi.org/10.1080/16583655.2018.1540179. 


\section{Supplementary materials}

\section{Adsorption isotherms}

Langmuir, Freundlich, and Tempkin isotherms have been applied to explain the reaction isotherm of the fabricated $\mathrm{K}$, UL, and KUL nanocomposites for the tested CR. The three models can be represented by equations 1,2 , and 3 , respectively [52-55]:

$$
\begin{aligned}
& \frac{C_{e}}{q_{e}}=\frac{1}{K_{L} Q_{o}}+\frac{C_{e}}{Q_{o}} \\
& \log q_{e}=\log K_{F}+\frac{1}{n} \log C_{e} \\
& q_{e}=\mathrm{B} \ln K_{T}+\mathrm{B} \ln C_{e}
\end{aligned}
$$

Here, $\mathrm{Q}_{\mathrm{o}}$ is the maximum amount of dye removed by K, UL, and KUL adsorbents $(\mathrm{mg} / \mathrm{g}) ; \mathrm{K}_{\mathrm{L}}, \mathrm{K}_{\mathrm{F}}$, and $\mathrm{K}_{\mathrm{T}}$ indicate to the Langmuir constant, Freundlich constant, and Tempkin binding constant, respectively. $\mathrm{B}(=\mathrm{RT} / \mathrm{b})$ is a constant associated with the adsorbed heat, $\mathrm{n}$ is the adsorption density, $\mathrm{T}$ is the absolute temperature, and $\mathrm{R}$ is the universal gas constant.

\section{Adsorption kinetics and mechanism}

Different adsorption mechanisms and kinetics models such as intra-particle diffusion, pseudo-first-order,pseudo-second-order, and simple Elovich kinetic model are used for identifying the adsorption mechanisms and kinetics models that best match with the adsorption of CR onto K, UL, and KUL adsorbents.

Equations 4 to 7 are used to represent the pseudo-first-order, pseudo-second-order, simple Elovich kinetic, and Intra-particle diffusion models, respectively [4-6, 57-60].

$$
\begin{aligned}
& \ln \left(\mathrm{q}_{\mathrm{e}}-\mathrm{q}_{\mathrm{t}}\right)=\ln \left(\mathrm{q}_{\mathrm{e}}\right)-\mathrm{k}_{1} \mathrm{t} \\
& \frac{t}{q_{t}}=\frac{1}{k_{2} q_{e}^{2}}+\frac{t}{q_{e}} \\
& q_{t}=\frac{1}{\beta} \ln \alpha \beta+\frac{1}{\beta} \ln t \\
& q_{t}=k_{3} t^{\frac{1}{2}}+I
\end{aligned}
$$

Where $\mathrm{k}_{1}, \mathrm{k}_{2}$, and $k_{3}$ represent rate constants of the pseudo-first-order, pseudo-secondorder, and Intra-particle propagation models. $I$ refers to a constant related to the boundary thickness. $\alpha$ implies the adsorption rate at time $=0 \mathrm{~min}(\mathrm{mg} / \mathrm{min})$ and $\beta$ represents the extent of surface coverage $(\mathrm{g} / \mathrm{mg})$.

Table S1. Conditions of experimental adsorption tests.

\begin{tabular}{c|c|c|c|c} 
Series & Dye concentration $(\mathrm{ppm})$ & $\begin{array}{c}\text { K, UL and KUL dose } \\
(\mathrm{g})\end{array}$ & $\begin{array}{c}\text { Temperature } \\
\left({ }^{\circ} \mathrm{C}\right)\end{array}$ & $\mathrm{pH}$ value \\
\hline 1 & $5,10,15,20$ and 25 & 0.02 & 25 & 7 \\
\hline 2 & 10 & $0.01,0.02,0.03,0.04$ and 0.05 & 25 & 7 \\
\hline 3 & 10 & 0.02 & $40,50,60,70,80$ and 90 & 7 \\
\hline 4 & 10 & 0.02 & 25 & $3,4,5,7,8$ and 10
\end{tabular}


Table S2. Characteristic wavenumbers of FTIR bands for K, UL and KUL adsorbents.

\begin{tabular}{|c|c|c|}
\hline Kaolin $(\mathbf{K}) \mathrm{cm}^{-1}$ & Algae (UL) $\mathrm{cm}^{-1}$ & KUL $\mathrm{cm}^{-1}$ \\
\hline 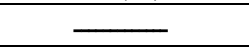 & 3916.734 & $\longrightarrow$ \\
\hline 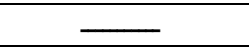 & 3777.007 & $\longrightarrow$ \\
\hline 3276.736 & 3424.703 & 3433.487 \\
\hline 2923.320 & 2928.542 & 2930.414 \\
\hline- & 2378.512 & 2377.646 \\
\hline \multicolumn{3}{|l|}{2860.117} \\
\hline 2505.973 & 2273.621 & $\longrightarrow$ \\
\hline$\longrightarrow$ & 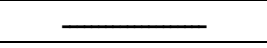 & 1863.178 \\
\hline$\longrightarrow$ & $\longrightarrow$ & 1643.076 \\
\hline 1480.394 & $\longrightarrow$ & $\longrightarrow$ \\
\hline$\longrightarrow$ & 1256.498 & $\longrightarrow$ \\
\hline$\longrightarrow$ & 1028.252 & 1089.546 \\
\hline 977.041 & 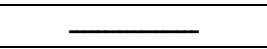 & $\longrightarrow$ \\
\hline 860.878 & 849.025 & 817.475 \\
\hline 712.458 & 781.231 & $\longrightarrow$ \\
\hline 690.145 & $\longrightarrow$ & 684.273 \\
\hline 581.607 & 547.517 & 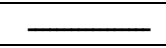 \\
\hline$\longrightarrow$ & 477.860 & 461.793 \\
\hline
\end{tabular}

Table S3. Comparison of the optimized conditions, removal\%, and adsorption capacity of different CR adsorbents relative to our $\mathrm{K}$, UL, and KUL nanoadsorbents.

\begin{tabular}{|c|c|c|c|c|}
\hline Adsorbent & Conditions & Removal \% & $\begin{array}{l}\text { Adsorption } \\
\text { capacity (mg/g) }\end{array}$ & Reference \\
\hline Natural kaolinite & & $48.36 \%$ & - & {$[34]$} \\
\hline phosphate-modified kaolinite & \multirow{4}{*}{$\begin{array}{l}\text { Time: } 120 \text { min Catalyst } \\
\text { dose: } 0.1 \mathrm{~g} / 150 \mathrm{OL} \\
\text { Dye Concentration: } 100 \\
\mathrm{mg} / \mathrm{L} \\
\text { pH: } 7.0 \\
\text { Temp: RT }\end{array}$} & $65.47 \%$ & - & [34] \\
\hline sulfate-modified kaolinite & & $63.2 \%$ & - & [34] \\
\hline $\begin{array}{l}\text { organic surfactant - modified } \\
\text { kaolinite }\end{array}$ & & $54.53 \%$ & - & {$[34]$} \\
\hline $\begin{array}{l}\text { sodium acetate- modified } \\
\text { kaolinite }\end{array}$ & & $46.86 \%$ & - & [34] \\
\hline Kaolin & $\begin{array}{l}\text { Time: } 60 \text { min } \\
\text { Catalyst dose: } 0.75 \mathrm{~g} \\
\text { solution } \mathrm{pH} \text { increased } \\
\text { from } 3 \text { to } 11\end{array}$ & $15.0 \%$ to $32.75 \%$ & 0.16 to $0.35 \mathrm{mg} / \mathrm{g}$. & [41] \\
\hline Kaolin & $\begin{array}{l}\text { Catalyst dose: } 5 \mathrm{~g} / \mathrm{L} \\
\text { Dye Concentration: } 150 \\
\text { mg/L } \\
\text { pH: } 7.5 \\
\text { Temp: } 30^{\circ} \mathrm{C} \\
\end{array}$ & $\begin{array}{l}\text { 100\% CR removal } \\
\text { using } 50 \mathrm{~g} / \mathrm{L}\end{array}$ & 5.44 & [42] \\
\hline Kaolin & $\begin{array}{l}\text { Time: } 40 \text { min } \\
\text { pH } 6.9 \\
\text { CR concentration }=100 \\
\mathrm{mg} / \mathrm{L} \\
\text { Catylast dose: } 0.1 \mathrm{~g} / 10 \mathrm{~mL}\end{array}$ & $64.24 \%$ & 5.94 & [92] \\
\hline $\begin{array}{l}\text { Cetyltrimethylammonium } \\
\text { bromidemodified Kaolin }\end{array}$ & $\begin{array}{l}\text { pH6.9 } \\
\text { time : } 40 \text { min } \\
\text { catalyst dose: } 10 \mathrm{~g} / \mathrm{L}\end{array}$ & $98.16 \%$ & $24.46 \mathrm{mg} / \mathrm{g}$ & \\
\hline Acid-activated red mud & $\begin{array}{l}\text { Contact time } 90 \mathrm{~min} \\
\text { Catalyst dose: } 5 \mathrm{~g} / \mathrm{L} \\
\text { Dye Concentration: } 20 \\
\text { mg/L } \\
\text { pH: } 7.0 \\
\text { Temp: RT }\end{array}$ & $\begin{array}{l}85 \% \text { to } 50 \% @ 10 \text { to } \\
90 \mathrm{mg} / \mathrm{CR} \\
\text { concentration }\end{array}$ & 4.05 & [93] \\
\hline $\begin{array}{l}\text { Natural kaolinite } \\
\mathrm{H}_{2} \mathrm{SO}_{4} \text {-treated kaolinite and } \\
\text { montmorillonite }\end{array}$ & $\begin{array}{l}\text { Time: } 120 \mathrm{~min} \\
\text { pH } 6.9 \\
\text { CR concentration }=100 \\
\mathrm{mg} / \mathrm{L} \\
\text { Catylast dose: } 0.1 \mathrm{~g} / 10 \mathrm{~mL}\end{array}$ & & $\begin{array}{l}0.024 \text { to } \\
0.033 \mathrm{mmol} \mathrm{g}-1\end{array}$ & [94] \\
\hline illite-kaolinite & time $=180 \mathrm{~min}$ & $8 \%$ & $5.7 \mathrm{mg} / \mathrm{g}$ & [95] \\
\hline
\end{tabular}




\begin{tabular}{|c|c|c|c|c|}
\hline Adsorbent & Conditions & Removal \% & $\begin{array}{l}\text { Adsorption } \\
\text { capacity (mg/g) }\end{array}$ & Reference \\
\hline & $\begin{array}{l}\text { CR conc. }=150 \mathrm{ppm} \\
\text { adsorbent dosage } 0.6 \mathrm{~g} / \mathrm{L} \\
\text { Temper: } \mathrm{RT}\end{array}$ & & & \\
\hline KUL & \multirow{3}{*}{$\begin{array}{l}\text { adsorbent dosage }=0.02 \mathrm{~g} \\
\mathrm{pH} 7 \text {, } \\
\text { Temperature: } 25^{\circ} \mathrm{C}\end{array}$} & $99 \%$ & 10.58 & \multirow{3}{*}{ This work } \\
\hline UL & & $81 \%$ & 15.5 & \\
\hline $\mathrm{K}$ & & $37.7 \%$ & 5 & \\
\hline
\end{tabular}

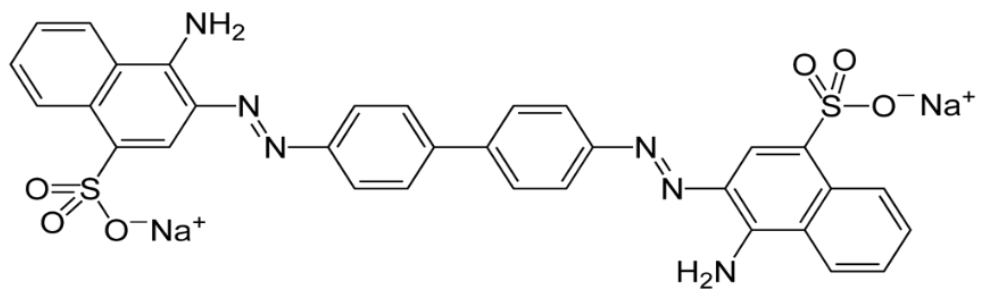

Figure S1. Structure of Congo red.
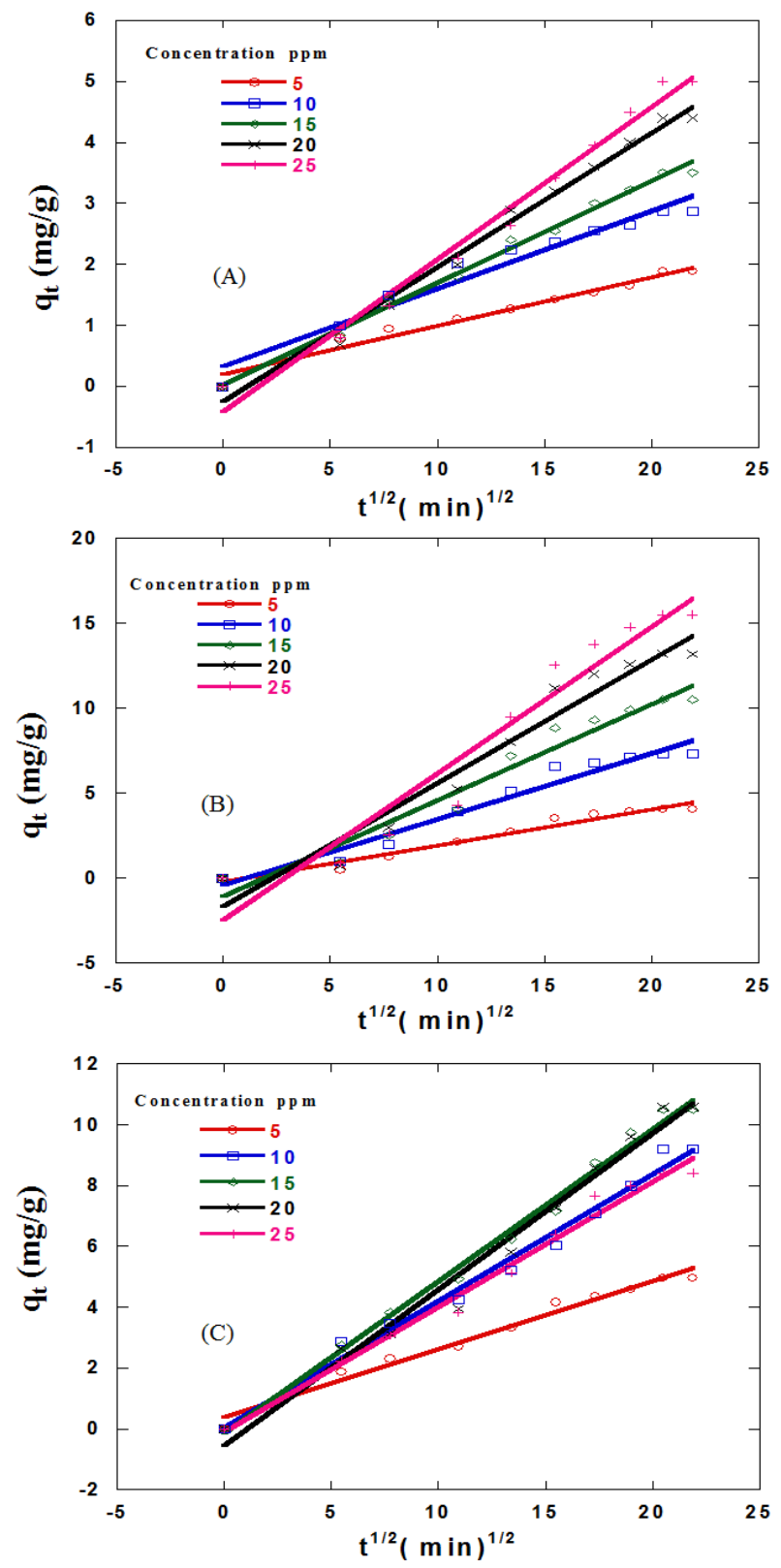

Figure S2. Intra-particle sorption kinetics of CR dye at $25^{\circ} \mathrm{C}$ and $\mathrm{pH} 7$ by $20 \mathrm{mg}$ of (A) K, (B)UL, and (C) KUL. 